\title{
NY-ESO-1 Based Immunotherapy of Cancer: Current Perspectives
}

\author{
Remy Thomas ${ }^{1}$, Ghaneya Al-Khadairi ${ }^{1}$, Jessica Roelands ${ }^{2,3}$, Wouter Hendrickx ${ }^{2}$, \\ Said Dermime ${ }^{4}$, Davide Bedognetti ${ }^{2}$ and Julie Decock ${ }^{1 *}$
}

${ }^{1}$ Cancer Research Center, Qatar Biomedical Research Institute, Qatar Foundation, Hamad Bin Khalifa University, Doha, Qatar, ${ }^{2}$ Immunology, Inflammation, and Metabolism Department, Tumor Biology, Immunology, and Therapy Section, Division of Translational Medicine, Sidra Medicine, Doha, Qatar, ${ }^{3}$ Department of Surgery, Leiden University Medical Center, Leiden, Netherlands, ${ }^{4}$ Translational Cancer Research Facility, National Center for Cancer Care and Research, Doha, Qatar

OPEN ACCESS

Edited by:

Dirk Jäger,

Universität Heidelberg,

Germany

Reviewed by:

Viktor Umansky,

Deutsches Krebsforschungszentrum

(DKFZ), Germany

Zong Sheng Guo,

Harvard University, United States

*Correspondence:

Julie Decock

jdecock@hbku.edu.qa,

juliedecock80@gmail.com

Specialty section:

This article was submitted to Cancer Immunity and Immunotherapy,

a section of the journal

Frontiers in Immunology

Received: 24 January 2018 Accepted: 16 April 2018

Published: 01 May 2018

Citation:

Thomas R, Al-Khadairi G,

Roelands J, Hendrickx W,

Dermime S, Bedognetti $D$ and Decock J (2018) NY-ESO-1 Based Immunotherapy of Cancer:

Current Perspectives.

Front. Immunol. 9:947.

doi: 10.3389/fimmu.2018.00947
NY-ESO-1 or New York esophageal squamous cell carcinoma 1 is a well-known cancertestis antigen (CTAs) with re-expression in numerous cancer types. Its ability to elicit spontaneous humoral and cellular immune responses, together with its restricted expression pattern, have rendered it a good candidate target for cancer immunotherapy. In this review, we provide background information on NY-ESO-1 expression and function in normal and cancerous tissues. Furthermore, NY-ESO-1-specific immune responses have been observed in various cancer types; however, their utility as biomarkers are not well determined. Finally, we describe the immune-based therapeutic options targeting NY-ESO-1 that are currently in clinical trial. We will highlight the recent advancements made in NY-ESO-1 cancer vaccines, adoptive T cell therapy, and combinatorial treatment with checkpoint inhibitors and will discuss the current trends for future NY-ESO-1 based immunotherapy. Cancer treatment has been revolutionized over the last few decades with immunotherapy emerging at the forefront. Immune-based interventions have shown promising results, providing a new treatment avenue for durable clinical responses in various cancer types. The majority of successful immunotherapy studies have been reported in liquid cancers, whereas these approaches have met many challenges in solid cancers. Effective immunotherapy in solid cancers is hampered by the complex, dynamic tumor microenvironment that modulates the extent and phenotype of the antitumor immune response. Furthermore, many solid tumor-associated antigens are not private but can be found in normal somatic tissues, resulting in minor to detrimental off-target toxicities. Therefore, there is an ongoing effort to identify tumor-specific antigens to target using various immune-based modalities. CTAs are considered good candidate targets for immunotherapy as they are characterized by a restricted expression in normal somatic tissues concomitant with a re-expression in solid epithelial cancers. Moreover, several CTAs have been found to induce a spontaneous immune response, NY-ESO-1 being the most immunogenic among the family members. Hence, this review will focus on NY-ESO-1 and discuss the past and current NY-ESO-1 targeted immunotherapeutic strategies.

Keywords: cancer-testis antigen, NY-ESO-1, adoptive T cell therapy, vaccine, immune checkpoint

\section{CANCER-TESTIS ANTIGENS (CTA)}

Cancer-testis antigens form a family of antigens that are encoded by 276 genes, comprising more than 70 gene families (1). Approximately $50 \%$ of all CTA genes form multigene families on the X chromosome and are referred to as CT-X genes (2). These CTAs are located in specific clusters along the chromosome with the highest density in the Xq24-q28 region (3). CTA expression is largely 
restricted to testicular germ cells and placenta trophoblasts with no or low expression in normal adult somatic cells $(3,4)$.

Interestingly, several CTAs have been found to be re-expressed in a variety of epithelial cancers. For example, using the RNA sequencing dataset from the Genotype-Tissue Expression project, Rooney et al. identified 60 CTAs with absent expression in normal tissues and ectopic expression in numerous tumor types, including melanoma, head and neck, lung, liver, stomach, and ovarian cancer (5). Across cancer types, tumors can be classified as CTA-rich, intermediate, or poor based on the frequency of CTA expression. CTA-rich tumors include melanoma, ovarian, lung, and bladder cancer; the group of CTA-moderate tumors comprises breast, bladder, and prostate cancer, while renal cell carcinoma, colorectal cancer, and lymphoma/leukemia are categorized as CTApoor tumors $(4,6)$. Several reports suggest that there might be a preference for specific CTA re-expression in certain tumor types, exemplified by MAGEA1-4 in 70\% of metastatic melanomas, ACRBP in $70 \%$ of ovarian tumors and NY-ESO- 1 in $46 \%$ of breast tumors (7). CTA expression patterns have also been associated with disease stage. For example, whereas no expression of the SSX family of CTAs could be observed in benign prostate tissue, $23 \%$ of metastatic prostate cancer lesions showed re-expression of SSX proteins (8). Although CTA expression may be increased in bulk primary tumors, this might not be reflected on the single cell level. For instance, microdissection of ovarian cancer specimens demonstrated considerable intra-tumoral heterogeneity of NY-ESO-1 expression (9). Heterogenous expression can also be found across metastatic foci originating from one primary lesion (10). Intratumoral heterogeneity could partly explain the different extent to which certain CTAs are re-expressed in tumors. In addition, discrepancies between RNA and protein expression levels are not uncommon and may contribute to the variety of expression levels reported. There is a great need for studies with direct comparison of RNA and protein expression levels in the same samples, which is impeded by the lack of specific commercially available CTA antibodies.

The mechanisms underlying the aberrant re-expression of CTAs include DNA demethylation and histone posttranslational modification with recent evidence also supporting a role for miRNA-mediated regulation $(2,11)$. Interestingly, demethylating agents such as 5-aza-2-deoxycytidine are capable to induce re-expression of certain CTAs specifically in tumor cells but not in normal epithelial cells (12-16).

Cancer-testis antigens are not only re-expressed in tumor tissues but they are also believed to be immunogenic proteins as many members of the family have been shown to elicit spontaneous cellular and humoral immune responses in cancer patients. The first CTA identified, MAGE-A1, was discovered through its ability to induce an autologous cytotoxic T lymphocyte response in a melanoma patient (17). Since then, several other CTAs have been identified as immunogenic tumor-associated antigens (TAAs) including SSX-2, NY-ESO-1, and various members of the BAGE, GAGE, and MAGE families $(2,18)$.

Despite the increasing amount of data on CTA expression in normal and neoplastic tissues, their functions remain largely elusive. Transgenic mouse models have revealed several CTA members to play a key role in male fertility (7). A handful of CTAs have been implicated in cell metabolism, cytoskeleton dynamics, double-strand break repair, maintenance of genomic integrity, and regulation of mRNA expression during spermatogenesis. Although increasing number of studies are demonstrating CTA re-expression in cancer, their functional role in oncogenesis is largely unexplored. More recent data points to a role for CTAs in the regulation of epithelial-to-mesenchymal transition as well as tumor cell survival (19).

Given their largely restricted expression in adult somatic tissues and their immunogenic potential, CTAs have been considered good candidate targets for cancer immunotherapy. To date, NY-ESO-1 is the most promising CTA for immune-based interventions as its tumor expression is clearly correlated with the induction of an immune response in a wide range of malignancies (2). Therefore, this review will focus on NY-ESO-1 in relation to its expression pattern and biological function; and will also discuss some of the past and recent developments in NY-ESO-1 tumor immunology and immunotherapy. This review does not aim to cover all available literature on NY-ESO-1 in cancer as this has become a very large area of research. Therefore, certain studies might have been missed in this review for which we apologize in advance.

\section{NY-ESO-1 EXPRESSION IN NORMAL TISSUES}

The CTA New York Esophageal Squamous Cell Carcinoma-1 (NY-ESO-1) is also known as cancer-testis antigen 1B (CTAG1B) and is encoded by the gene $C T G A G 1 B$ which is located on the $\mathrm{Xq} 28$ region of the $\mathrm{X}$ chromosome.

NY-ESO-1 is an archetypical example of a CTA with restricted expression to germ cells and placental cells and re-expression in tumor cells. During embryonic development, NY-ESO-1 expression can be detected as early as 13 weeks and is the highest at 22-24 weeks (20). While NY-ESO-1 expression is maintained in the spermatogonia and primary spermatocytes, its expression quickly decreases in the female oogonia (3, 20-22). RNA, but not protein, expression of NY-ESO-1 has been detected at low levels in ovarian and endometrial tissue, albeit its biological relevance is as yet unclear $(21,23)$.

NY-ESO-1 is an 18 - $\mathrm{kDa}$ protein with 180 amino acids featuring a glycine-rich $\mathrm{N}$-terminal region and a strongly hydrophobic C-terminal region with a Pcc-1 domain. The NY-ESO-1 protein has been shown to be homologous to two other CTA located in the same region; LAGE-1 and ESO3 (24). While NY-ESO-1 and LAGE-1 encode very homologous proteins with restricted expression in adult testis, the ESO3 protein has a rather low similarity with both and has been reported to be expressed in various somatic tissues (25). Screening of cDNA expression libraries for $\mathrm{T}$ cell epitope discovery has revealed that NY-ESO-1 can be generated from an alternative open reading frame, resulting in a 58 amino acid-long protein that is recognized by tumor-reactive $\mathrm{T}$ cells (26).

Although very little is known about the biological function of NY-ESO-1, possible functions can be deducted from its structure and expression pattern. The presence of the conserved 
Pcc-1 domain suggests that it might be involved in cell cycle progression and growth (27). Coexpression with melanoma antigen gene C1, a member of the MAGE family of CTAs (28), further supports involvement in cell cycle progression and apoptosis given the prominent role of MAGE proteins in these cellular processes (29). In addition, its restricted expression pattern suggests that it may have a role in germ cell self-renewal or differentiation. This notion is further supported by the nuclear localization of NY-ESO-1 in mesenchymal stem cells in contrast to the predominant cytoplasmic expression in cancer cells. Upon differentiation of mesenchymal stem cells, NY-ESO-1 expression is downregulated which suggests a possible role in cell proliferation of stem cells and cancer cells (30). Furthermore, NY-ESO-1 expression is increased in glioma cancer stem cells compared to differentiated cells, concurrent with histone acetylation and DNA hypomethylation (31).

\section{NY-ESO-1 EXPRESSION IN CANCER}

\section{Tumor Expression}

NY-ESO-1 expression has been reported in a wide range of tumor types, including neuroblastoma, myeloma, metastatic melanoma, synovial sarcoma, bladder cancer, esophageal cancer, hepatocellular cancer, head and neck cancer, non-small cell lung cancer, ovarian cancer, prostate cancer, and breast cancer (21, 32-46). Within these tumor types, the expression frequency of NY-ESO-1 differs greatly with the most commonly expressing tumors being myxoid and round cell liposarcoma (89-100\%), neuroblastoma (82\%), synovial sarcoma (80\%), melanoma (46\%), and ovarian cancer $(43 \%)(37,47-51)$. Other tumor types show protein expression of NY-ESO-1 in the range of 20-40\%. In addition, numerous studies have reported RNA expression data which might differ considerably from protein expression levels as determined by immunohistochemistry; and only few studies have investigated both RNA and protein expression.

Important to note is that the majority of cancer types show a heterogeneous expression of NY-ESO-1, which could limit the treatment response to NY-ESO-1, targeted treatment. The most homogenous expression has been reported in myxoid and round cell liposarcomas (94\%) and synovial sarcomas (70\%) which might be related to the promising results that have been obtained in adoptive cellular immunotherapy trials $(47,49)$.

\section{Humoral and Cellular Immune Response}

The first evidence of a spontaneous immune response against NY-ESO-1 was reported in an esophageal cancer patient (52). Using the tumor mRNA of one patient with a squamous cell carcinoma of the esophagus, the authors constructed a tumor cDNA expression library that was immunoscreened with the serum of the same patient. Using the SEREX technology (Serological analysis of recombinant cDNA expression libraries), NY-ESO-1 was identified as a tumor antigen that could elicit high-titer IgG humoral responses.

Humoral immune responses against NY-ESO-1 can be detected in a variety of cancer patients, including patients with colorectal, lung, breast, prostate, gastric, and hepatocellular cancer (53-61).
As most of these studies focus on one cancer type, the study of Oshima et al. is worth noting as they performed a large serological study on 1,969 specimens from patients with various cancer types (62). The authors could detect serum NY-ESO-1 autoantibodies across all cancers, with the highest frequency in esophageal cancer $(32 \%)$, followed by lung cancer (13\%), hepatocellular cancer (11\%), prostate and gastric cancer (10\%), colorectal cancer $(8 \%)$, and breast cancer (7\%). Analysis of healthy individuals revealed no spontaneous NY-ESO-1 humoral response.

NY-ESO-1 has also been shown to induce a cellular immune response. The first report of a simultaneous humoral and cellular response against NY-ESO-1 was observed in a metastatic melanoma patient with a high-titer antibody response (63). Three HLA-A2 restricted epitopes in NY-ESO-1 were identified as the recognition sites for CD8+ cytotoxic T lymphocytes. In a followup study, the same team validated their findings by detection of NY-ESO-1-specific CD8+ T cells in 10 out of 11 melanoma patients who carry NY-ESO-1 antibodies (64). In a later study, they also identified three HLA-DRB $4^{\star} 0101-0103$, MHC class II epitopes that were recognized by CD4+ T lymphocytes from two melanoma patients (65). In addition, others identified HLADRB ${ }^{\star} 0401$ and HLA-DP4 restricted epitopes in the carboxyterminal end of NY-ESO-1 which can be recognized by CD4+ $\mathrm{T}$ lymphocytes from melanoma patients (66-69). The peptide containing the HLA-DP4-restricted epitope could also generate HLA-A2-restricted CD8+T cells, suggesting that the peptide could be used as a cancer vaccine to induce both CD4+ and CD8+ T cell responses (70). This opens up the number of immunotherapeutic approaches that can be employed against NY-ESO-1-positive tumors inducing the humoral immune system as well as the cellular CD4+ and CD8+ T cell compartments, either individually or in combination. Interestingly, in healthy individuals NY-ESO-1 specific CD4+ T-cell precursors were found to be actively suppressed by regulatory $\mathrm{T}$ cells, suggesting that the cytokine milieu of the tumor microenvironment can dictate and impede natural NY-ESO-1 antitumor immune responses $(71,72)$. This notion is of great importance and should be taken into account during the design of novel immune-based interventions.

\section{NY-ESO-1 as Biomarker}

NY-ESO-1 expression has been found across tumor types to correlate with several characteristics of advanced disease, including higher differentiation grade, lymph node metastasis, and clinical stage (23). The value of NY-ESO-1 expression as a prognostic biomarker remains controversial. While its expression has been linked to a poor clinical outcome in some cancers, no correlation or conflicting results have been found in others. For instance, in non-small cell lung cancer, hepatocellular carcinoma, head and neck cancer, gastrointestinal cancer, multiple myeloma, and malignant melanomas NY-ESO-1 tumor expression has been associated with a higher risk of recurrence, poor treatment response and shorter survival (73-83). In contrast, in non-Hodgkin's lymphoma NY-ESO-1 tumor expression was associated with early stage disease (84). Early reports on ovarian and breast cancer did not show any significant correlation with prognosis $(37,85,86)$. Immune responses to NY-ESO-1 have also been investigated in the context of circulating biomarkers, providing a non-invasive 
way for monitoring disease progression and treatment response. The extent of a NY-ESO-1-specific humoral immune response has been found to increase with disease progression and to decrease with disease regression (32, 33, 38, 60, 62, 87-89). A comprehensive overview of NY-ESO-1 expression and immunogenicity in different cancers has been provided by Esfandiary and Ghafouri-Fard (22). After the publication of that review, new findings showed that the detection rate of NY-ESO-1 antibodies in esophageal cancer gradually increases with disease stage, going from $16 \%$ in stage I to $42 \%$ in stage IV (62). Further, in colorectal cancer, the presence of NY-ESO-1 antibodies has been recently correlated with several prognostic clinicopathological parameters including depth of tumor invasion, clinical stage, lymph node, and distant metastasis (89). Changes in NY-ESO-1 antibodies over time can be indicative of disease regression and could be used as markers for disease monitoring as demonstrated in 12 patients with different tumor types (88). In four out of five patients (two bladder cancer, two melanoma, one non-small cell lung cancer) with a decrease in NY-ESO-1 humoral response, a reduction in tumor burden and/or metastases was observed. Likewise, NY-ESO-1T-cell responses have been investigated as prognostic markers. In metastatic melanoma, the presence of circulating NY-ESO-1specific $\mathrm{T}$ lymphocytes has been associated with better prognosis, improving overall survival from 6 to 21 months (90).

\section{NY-ESO-1 DIRECTED IMMUNOTHERAPY}

NY-ESO-1 is widely believed to be a good candidate target for immunotherapy and some promising results have been obtained in early phase I/II studies. Its restricted expression in normal tissues in combination with its widespread expression across tumor types renders NY-ESO-1 a target with limited off-target toxicities and broad applications in numerous cancer types. Furthermore, its strong immunogenic nature suggests that there is an opportunity to boost the natural immune response against this TAA. To date, there are 12 active, 31 recruiting, and 5 proposed clinical trials targeting NY-ESO-1 using various immune-based interventions (http://www.clinicaltrials.gov). In this review, we will discuss the ongoing clinical trials, summarized in Tables 1-3, and highlight some of the completed trials using a NY-ESO-1 vaccination approach, adoptive cellular therapy, or combination treatment with immune checkpoint inhibitors (Figure 1).

\section{NY-ESO-1 Cancer Vaccines}

The current NY-ESO-1 cancer vaccine trials have evolved considerably since the first clinical trials that were conducted more than one decade ago. Many advances have been made in peptide discovery and vaccine formulation. We now have an armatorium of individual synthetic peptides, individual and complexed

TABLE 1 | NY-ESO-1 cancer vaccines currently in clinical trial.

\begin{tabular}{|c|c|c|c|c|}
\hline NCT number & Other IDs & Interventions & Conditions & Status \\
\hline NCT01967758 & $13-012 \mathrm{~A}$ & NY-ESO-1 bacterial vaccine ADU-623 & $\begin{array}{l}\text { Astrocytic tumors|glioblastoma } \\
\text { multiforme|anaplastic astrocytoma|brain tumor }\end{array}$ & $\begin{array}{l}\text { Active, not } \\
\text { recruiting }\end{array}$ \\
\hline NCT01536054 & | 199911|NCl-2011-02964 & $\begin{array}{l}\text { ALVAC(2)-NY-ESO-1 (M)/TRICOM vaccine| } \\
\text { mTOR inhibitor (Sirolimus) }\end{array}$ & $\begin{array}{l}\text { Stage II-IV and recurrent fallopian tube cancer/ } \\
\text { ovarian epithelial cancer/primary peritoneal } \\
\text { cavity cancer }\end{array}$ & $\begin{array}{l}\text { Active, not } \\
\text { recruiting }\end{array}$ \\
\hline NCT02833506 & $\begin{array}{l}\text { | 277115|NCl-2016-00811| } \\
\text { P30CA016056|R01CA158318 }\end{array}$ & $\begin{array}{l}\text { Recombinant NY-ESO-1 Protein vaccine| } \\
\text { mTOR inhibitor (Sirolimus) }\end{array}$ & $\begin{array}{l}\text { Stage II-IV and recurrent fallopian tube cancer/ } \\
\text { ovarian epithelial cancer/primary peritoneal } \\
\text { cavity cancer }\end{array}$ & $\begin{array}{l}\text { Not yet } \\
\text { recruiting }\end{array}$ \\
\hline NCT02224599 & Kirovax 003|BSK01 DC vaccine & Peptide-pulsed DC vaccine & Advanced solid tumors & Recruiting \\
\hline NCT02692976 & EudraCT 2012-002531-29 & $\begin{array}{l}\text { Multi peptide (NY-ESO-1, MUC1) -pulsed myeloid } \\
\text { and plasmacytoid DC vaccine }\end{array}$ & Prostate cancer & $\begin{array}{l}\text { Active, not } \\
\text { recruiting }\end{array}$ \\
\hline NCT01883518 & MC-01-2013|ADCVCTAST & $\begin{array}{l}\text { Allogeneic tumor lysate (NY-ESO-1, } \\
\text { MAGE-A3) -pulsed DC vaccine }\end{array}$ & Soft tissue sarcoma & Recruiting \\
\hline NCT02334735 & GCO 14-0780 & $\begin{array}{l}\text { Multi peptide (NY-ESO-1 and Melan-A/MART-1) - } \\
\text { pulsed DC vaccine }\end{array}$ & Melanoma & Recruiting \\
\hline NCT02122861 & ID-LV305-2013-001 & DC lentiviral vector vaccine (LV305) & Melanoma/non-small cell lung cancer/sarcoma & $\begin{array}{l}\text { Active, not } \\
\text { recruiting }\end{array}$ \\
\hline NCT02387125 & IMDZ-C131 & $\begin{array}{l}\text { CMB305 (peptide-pulsed DC vaccine LV305 + } \\
\text { G305 recombinant NY-ESO-1 protein vaccine)| } \\
\text { TLR4 agonist (G100) }\end{array}$ & $\begin{array}{l}\text { Sarcoma|melanoma|non-small cell lung } \\
\text { cancer|ovarian cancer }\end{array}$ & Recruiting \\
\hline NCT02129075 & $\begin{array}{l}\text { NCl-2014-00898|CITN-07- } \\
\text { FLT3L|U01CA154967 }\end{array}$ & $\begin{array}{l}\text { DEC-205/NY-ESO-1 Fusion Protein vaccine } \\
\text { (CDX-1401)|Recombinant Flt3 Ligand (CDX-301) }\end{array}$ & Stage II-IV melanoma & $\begin{array}{l}\text { Active, not } \\
\text { recruiting }\end{array}$ \\
\hline NCT02166905 & $\begin{array}{l}\text { I 248613|NCl-2014- } \\
00771 \mid \mathrm{P} 30 \mathrm{CA} 016056\end{array}$ & $\begin{array}{l}\text { DEC-205/NY-ESO-1 Fusion Protein (CDX-1401)| } \\
\text { IDO1 inhibitor (Epacadostat) }\end{array}$ & $\begin{array}{l}\text { Fallopian tube carcinoma|ovarian } \\
\text { carcinoma|primary peritoneal carcinoma }\end{array}$ & Recruiting \\
\hline NCT02750995 & AZACTA & $\begin{array}{l}\text { Multi peptide vaccine (NY-ESO-1, PRAME, MAGE-A3, } \\
\text { WT-1)|demethylating agent Decitabine }\end{array}$ & $\begin{array}{l}\text { Myelodysplastic syndrome|acute myeloid } \\
\text { leukemia }\end{array}$ & Recruiting \\
\hline
\end{tabular}

CMB305, peptide-pulsed DC vaccine LV305 + G305 recombinant NY-ESO-1 protein vaccine; DC, dendritic cell; CDX-1401, DEC-205/NY-ESO-1 Fusion Protein vaccine. 
TABLE 2 | NY-ESO-1 adoptive T cell therapy modalities currently in clinical trial.

\begin{tabular}{|c|c|c|c|c|}
\hline NCT number & Other IDs & Interventions & Conditions & Status \\
\hline NCT02366546 & $1301-01$ & TBI-1301 & Advanced solid tumors & Recruiting \\
\hline NCT02869217 & $1301-02$ & TBI-1301 & Advanced solid tumors & Recruiting \\
\hline NCT03250325 & $1301-03$ & TBI-1301 & Synovial sarcoma & Recruiting \\
\hline NCT03047811 & NY-TCR WXH 2016 & NY-ESO-1 TCR-T cells & Advanced solid tumors & Recruiting \\
\hline NCT02457650 & 201504002 & NY-ESO-1 TCR-T cells & Metastatic solid tumors & Recruiting \\
\hline NCT01795976 & ATTACK-OG|12_DOG14_22 & NY-ESO-1 TCR-T cells & Esophageal cancer & Active, not recruiting \\
\hline NCT03093350 & H-39209 TACTIC & $\begin{array}{l}\text { Multi TAA T cells (NY-ESO-1, MAGEA4, PRAME, } \\
\text { survivin and SSX2) }\end{array}$ & Breast cancer & Not yet recruiting \\
\hline NCT03192462 & H-40378 TACTOPS & $\begin{array}{l}\text { Multi TAA T cells (NY-ESO-1, MAGEA4, PRAME, } \\
\text { survivin and SSX2) }\end{array}$ & Pancreatic cancer & Not yet recruiting \\
\hline NCT02239861 & H-35425, TACTASOM & $\begin{array}{l}\text { Multi TAA T cells (NY-ESO-1, MAGEA4, PRAME, } \\
\text { survivin and SSX2) }\end{array}$ & Rhabdomyosarcoma & Recruiting \\
\hline NCT02291848 & H-35626, TACTAM & $\begin{array}{l}\text { Multi TAA T cells (NY-ESO-1, MAGEA4, PRAME, } \\
\text { survivin and SSX2) }\end{array}$ & Multiple myeloma & Recruiting \\
\hline NCT02494167 & H-36346 ADSPAM & $\begin{array}{l}\text { Multi TAA T cells (WT1, NY-ESO-1, PRAME, } \\
\text { and survivin) }\end{array}$ & $\begin{array}{l}\text { Acute myeloid leukemia, myelodysplastic } \\
\text { syndrome }\end{array}$ & Recruiting \\
\hline NCT03175705 & Beijing Youan Ethics[2017]06 & Multi TAA T cells (GPC-3, NY-ESO-1, AFP) & Hepatocellular carcinoma & Recruiting \\
\hline NCT02774291 & $\begin{array}{l}2015-5254 \mid \mathrm{NCl}-2015- \\
01781 \mid \mathrm{P} 30 \mathrm{CA0} 13330\end{array}$ & Murine NY-ESO-1 TCR-T cells & Metastatic solid tumors & Not yet recruiting \\
\hline NCT01967823 & $130214 \mid 13-C-0214$ & Murine NY-ESO-1 TCR-T cells & Metastatic solid tumors & Recruiting \\
\hline NCT01567891 & ADP-0011-001|230612 & NY-ESO-1 $1^{\mathrm{c} 259}-\mathrm{T}$ cells & Ovarian cancer & Recruiting \\
\hline NCT01350401 & ADP 01611 & NY-ESO-1 $1^{\mathrm{c} 259}-\mathrm{T}$ cells & Metastatic melanoma & Active, not recruiting \\
\hline NCT01343043 & ADP 04511 & NY-ESO-1 $1^{\mathrm{c} 259}-\mathrm{T}$ cells & Synovial sarcoma & Recruiting \\
\hline NCT02992743 & ADP-0011-007 & NY-ESO-1 $1^{\mathrm{c} 259}-\mathrm{T}$ cells & Advanced myxoid, round cell liposarcoma & Recruiting \\
\hline NCT01892293 & ADP-0011-002 & NY-ESO-1 $1^{\mathrm{c} 259}-\mathrm{T}$ cells & Multiple myeloma & Active, not recruiting \\
\hline NCT02588612 & ADP-0011-004 & NY-ESO-1 $1^{\mathrm{c} 259}-\mathrm{T}$ cells & Non-small-cell lung cancer & Recruiting \\
\hline NCT01352286 & ADP 01411 & NY-ESO-1 ${ }^{\mathrm{c} 259}-\mathrm{T}$ cells|stem cell transplantation & Multiple myeloma & Active, not recruiting \\
\hline NCT03029273 & $2016-63$ & TAEST16001 & Recurrent non-small cell lung cancer & Recruiting \\
\hline NCT03159585 & TS20161229 & TAEST16001 & solid tumors & Recruiting \\
\hline
\end{tabular}

TAA, tumor-associated antigen; TAEST16001, TCR affinity enhancing specific T cell therapy with autologous T cells transduced with affinity-enhanced NY-ESO-1 TCR; TBI-1301, NY-ESO-1 specific TCR-transduced T cells; TCR, T cell receptor.

recombinant proteins, as well as a variety of adjuvant formulations to our disposal. Various adjuvants have been rigorously tested for their ability to enhance cytotoxic CD8+ T lymphocyte activity in response to exposure to MHC class I-restricted peptides. These adjuvants vary from granulocyte/macrophage colony-stimulating factor to montanide-ISA-51 (Montanide), polyinosinic-polycytidylic acid-stabilized by lysine and carboxymethyl cellulose (PolyICLC), incomplete Freund's adjuvant, saponin-based adjuvant (ISCOMATRIX), cholesteryl pullulan, and monophosphoryl lipid A $(91,92)$. A combination of various factors has been proposed as novel adjuvant (APH); consisting of alum, polysaccharides and the short synthetic innate defense-regulator peptide $\mathrm{HH} 2$ (93). NY-ESO-1 vaccination with this adjuvant significantly increased humoral and cellular responses and reduced the melanoma burden in mice. Another strategy to enhance vaccination efficacy is to induce CD4+ immune responses to support the priming and maintenance of CD8+ cytotoxic T lymphocytes (92). To date, 21 distinct epitopes restricted to at least five different HLAclass II alleles have been identified in NY-ESO-1. The peptides NY-ESO- $1_{80-109}$ and NY-ESO- $1_{157-165}$, associated with, respectively, $\mathrm{CD} 4+$ and CD8+ T cell responses, have been shown to be the most immunogenic. Using full-length recombinant protein can further enhance the extent of the induced immune responses as both class I and class II epitopes are available for antigen presentation and processing. For instance, vaccination of melanoma patients with recombinant full-length NY-ESO-1 alone or in combination with the ISCOMATRIX adjuvant resulted in a strong induction of NY-ESO-1 specific antibodies, as well as an increase in specific CD4+ and CD8+ T cells (94). Using longer peptides also has the potential to induce a stronger immune response. For example, vaccination with the 20 -mer NY-ESO-1 $1_{91-110}$ peptide, covering multiple epitopes, induced both humoral and cellular CD4+ and $\mathrm{CD} 8+\mathrm{T}$ cell responses. Furthermore, stable disease was achieved in 3 out of 10 cancer patients (95). Another approach to enhance NY-ESO-1 vaccination responses is the use of a prime and boost schedule, consisting of an initial vaccination, the prime, with 1 cancer vaccine followed by administration of a second vaccine, the boost. Using a recombinant NY-ESO-1 vaccine/recombinant fowlpox-NY-ESO-1 vaccine prime-boost regimen, both humoral and cellular responses against a broad range of NY-ESO-1 epitopes have been observed $(96,97)$. Other modifications to the acellular vaccine approach currently in 
TABLE 3 | NY-ESO-1 combinatorial immune-based interventions currently in clinical trial.

\begin{tabular}{|c|c|c|c|c|}
\hline NCT number & Other IDs & Interventions & Conditions & Status \\
\hline NCT01946373 & MAT-02|2012-000450-63 & Peptide-pulsed DC vaccine|TILs & Melanoma & Recruiting \\
\hline NCT01176474 & MCC-15651|NCl-8316 & $\begin{array}{l}\text { NY-ESO- } 1_{157-165} / g_{10} 100_{280-288} \text { vaccine|PD-1 inhibitor (Nivolumab)| } \\
\text { PD-1 inhibitor (Nivolumab) + CTLA-4 inhibitor (Ipilimumab) }\end{array}$ & Stage III-IV melanoma & $\begin{array}{l}\text { Active, not } \\
\text { recruiting }\end{array}$ \\
\hline NCT01176461 & $\begin{array}{l}\text { MCC-15400|NCl-P-7997| } \\
\text { CA209-006/007|10-15526-99-01 }\end{array}$ & 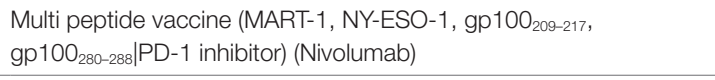 & Melanoma & $\begin{array}{l}\text { Active, not } \\
\text { recruiting }\end{array}$ \\
\hline NCT02609984 & IMDZ-C232 & CMB305|PD-L1 inhibitor (Atezolizumab) & Sarcoma & $\begin{array}{l}\text { Active, not } \\
\text { recruiting }\end{array}$ \\
\hline NCT03206047 & $\begin{array}{l}\mathrm{NCl}-2017-01030|| \\
285416|10017| \mathrm{P} 30 \mathrm{CA} 016056\end{array}$ & $\begin{array}{l}\text { DEC-205/NY-ESO-1 fusion protein vaccine (CDX- } \\
\text { 1401)|demethylating agent|PD-L1 inhibitor (atezolizumab) }\end{array}$ & $\begin{array}{l}\text { Recurrent fallopian } \\
\text { tube carcinoma|ovarian } \\
\text { carcinoma|primary peritoneal } \\
\text { carcinoma }\end{array}$ & Recruiting \\
\hline NCT03017131 & $\begin{array}{l}\text { i } 283616 \mid \mathrm{NCl}-2016- \\
\text { 01477|P30CA016056|P50CA159981 }\end{array}$ & NY-ESO-1 TCR-T cells|demethylating agent & $\begin{array}{l}\text { Recurrent fallopian } \\
\text { tube carcinomalovarian } \\
\text { carcinoma|primary peritoneal } \\
\text { carcinoma }\end{array}$ & $\begin{array}{l}\text { Not yet } \\
\text { recruiting }\end{array}$ \\
\hline NCT01333046 & H-27471-TACTAL|TACTAL & $\begin{array}{l}\text { Multi TAA T cells (NY-ESO-1, MAGEA4, PRAME, survivin and } \\
\text { SSX2)|decitabine }\end{array}$ & $\begin{array}{l}\text { Hodgkin lymphoma|non- } \\
\text { Hodgkin lymphoma|Hodgkin } \\
\text { disease }\end{array}$ & Recruiting \\
\hline NCT01697527 & $12-000153 \mid \mathrm{NCl}-2012-01548$ & NY-ESO-1 TCR-T cells|NY-ESO-1 157-165 $_{\text {peptide-pulsed DC vaccine }}$ & Advanced solid tumors & Recruiting \\
\hline NCT03240861 & $\begin{array}{l}\text { 15-000511|NCl-2017-00896|Ribas } \\
\text { NYESO SCT Cancer|P30CA016042 }\end{array}$ & $\begin{array}{l}\text { NY-ESO-1 TCR-transduced peripheral blood mononuclear } \\
\text { cells and peripheral blood stem cells }\end{array}$ & Advanced solid tumors & Recruiting \\
\hline NCT02650986 & $\begin{array}{l}\text { I 258514|NCI-2015- } \\
\text { 02080|P30CA016056 }\end{array}$ & NY-ESO-1 TCR-T cells|TGFbDNRII-transduced TILs & Advanced solid tumors & Recruiting \\
\hline NCT03168438 & ADP-0011-008|KEYNOTE-487 & NY-ESO-1 ${ }_{\mathrm{c} 259}-\mathrm{T}$ cells|PD-1 inhibitor (pembrolizumab) & Multiple myeloma & Recruiting \\
\hline NCT02775292 & $\begin{array}{l}\text { NYM|15-001433|NCl-2016-00201| } \\
\text { Ribas NYESO + Nivolumab } \\
\text { Cancer|P30CA016042 }\end{array}$ & $\begin{array}{l}\text { NY-ESO-1 TCR-T cells|NY-ESO-1 } 157-165 \text {-pulsed DC vaccine| } \\
\text { PD-1 inhibitor (nivolumab) }\end{array}$ & Advanced solid tumors & Recruiting \\
\hline NCT02070406 & $\begin{array}{l}\text { 13-001624|NCl-2014-00221| } \\
\text { P30CA016042 }\end{array}$ & $\begin{array}{l}\text { NY-ESO-1 TCR-T cells|NY-ESO-1 }{ }_{157-165} \text { pulsed DC vaccine| } \\
\text { CTLA-4 inhibitor (ipilimumab) }\end{array}$ & Advanced solid tumors & Recruiting \\
\hline
\end{tabular}

CMB305, peptide-pulsed DC vaccine LV305 + G305 recombinant NY-ESO-1 protein vaccine; CDX-1401, DEC-205/NY-ESO-1 Fusion Protein vaccine; DC, dendritic cell; TCR, T cell receptor; TAA, tumor-associated antigen; TILs, tumor-infiltrating lymphocytes; PD-L1, programmed death ligand 1; CTLA-4, cytotoxic T-lymphocyte-associated protein 4; PD-1, programmed cell death protein 1.

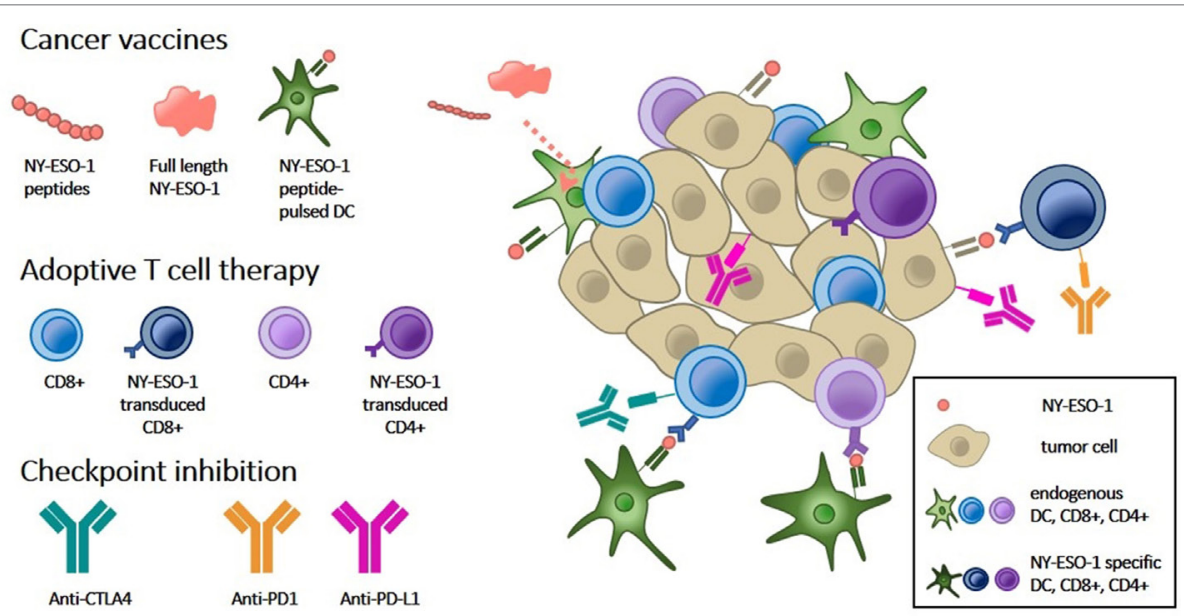

FIGURE 1 | Overview of NY-ESO-1 targeted approaches for cancer immunotherapy. Immune-mediated tumor rejection can be induced by targeting tumor-specific NY-ESO-1 expression by the following three approaches: (1) cancer vaccines consisting of NY-ESO-1-derived peptides or full-length protein are taken up by dendritic cells (DCs, light green) and subsequently presented to the tumor immune microenvironment. Vaccination of DCs pulsed with NY-ESO-1 peptides (dark green) directly stimulates T cells. (2) Adoptive T cell therapy by transduction of CD8+ or CD4+ T cells with NY-ESO-1 T cell receptors (dark blue, dark purple, respectively) directs them against NY-ESO-1, presented by tumor cells (cream). (3) Both types of immunotherapy can be combined with immune checkpoint inhibitors which block inhibitory signals between DCs and T cells (anti-CTLA-4) and between T cells and tumor cells (anti-PD1 and anti-PD-L1). 
clinical trial are the use of a bacterial vector for NY-ESO-1 vaccine delivery (NCT01967758, Table 1); and combinatorial treatment of NY-ESO-1 vaccination with the mTOR inhibitor Sirolimus (NCT01536054, NCT02833506, Table 1) or with the demethylating agent Decitabine (NCT02750995, Table 1).

Since dendritic cells (DCs) are the dominant antigenpresenting cells and are strong activators of $\mathrm{T}$ cells, numerous studies have investigated the use of peptide-pulsed DCs as cellular vaccines (98). Further advances in the field have demonstrated an added benefit of including toll-like receptor (TLR) agonists as an adjuvant. The rationale behind this lies in the TLR-mediated activation of DCs, and the induction of T helper 1-cell responses (99). Indeed, combination treatment with a TLR3 (Hiltonol), TLR7 (imiquimod), TLR7/8 (resiquimod), or TLR9 (CpG 7909) agonist has been shown to enhance humoral and cellular responses in a significant proportion of cancer patients (100-102). The safety and efficacy of NY-ESO-1-pulsed DCs is currently under study in various clinical trials (Table 1), either alone (NCT02692976, NCT01883518, NCT02334735, NCT02224599) or in combination with a NY-ESO-1 protein vaccine and TLR4 agonist (NCT02387125). Specific targeting of the DCs can also be achieved using the DEC-205/NY-ESO-1 fusion protein (CDX-1401), which targets the NY-ESO-1 protein for DC endocytosis through the DEC-205 receptor. This fusion protein is currently in clinical trial in combination with the recombinant Flt3 ligand CDX-301 to promote DC development (NCT02129075, Table 1), or with the IDO1 inhibitor Epacadostat (NCT02166905, Table 1), or with infusion of tumor-infiltrating lymphocytes (TILs) (NCT01946373, Table 3). Cancer vaccines can also be targeted toward DCs through TLRs. One example of this approach is the use of a NY-ESO-1 encoding LV305 lentivirus, targeting DCs through TLR3 and TLR7, which induced a strong cellular immune response with significant disease regression in one patient with metastatic, treatment-refractory synovial sarcoma (103). This case report is part of an ongoing phase I clinical trial (NCT02122861, Table 1) investigating the use of intradermal NY-ESO-1-specific lentiviral DC-targeting in melanoma, non-small cell lung cancer, ovarian cancer, and sarcoma. A second example of acellular dendritic-based therapy is the use of Fc receptor-mediated uptake of liposome-encapsulated adjuvants and/or drugs with subsequent DC activation (104). Combining a NY-ESO-1 protein vaccine with the liposome-encapsulated chemotherapeutic drug doxorubicin and the demethylation agent Decitabine enhanced the specific humoral and CD8+ immune responses in 67 and $50 \%$ of patients with relapsed epithelial ovarian cancer (105). Stable disease was obtained in 50\% of patients (5/10) with a median duration of 6.3 months, and one patient had a partial response (10\%) with a duration of 5.8 months.

\section{NY-ESO-1 Adoptive T Cell Therapy}

NY-ESO-1 cancer vaccines have proven to elicit both humoral and cellular responses; however, few complete responses have been obtained using this approach. Therefore, the focus for immunebased intervention against NY-ESO-1 has largely changed over time toward the development of genetically engineered Tlymphocytes. Based on the knowledge gained from vaccine studies, T cells directed against specific NY-ESO-1 epitopes have been engineered and tested for their ability to eradicate tumors. Adoptive T cell therapy with HLA-A2 restricted NY-ESO-1/LAGE-1 transduced CD8+ T cells has improved the clinical response rates and overall survival of treatment-refractory melanoma and synovial cell sarcoma patients. In a first cohort, approximately half of patients with metastatic melanoma or synovial cell sarcoma who received NY-ESO-1 transduced CD8+ T cells and IL-2 showed a clinical response (106). 2 out of 11 metastatic melanoma patients exhibited a complete response and 1 patient had a partial response. Four out of six patients with synovial cell sarcoma experienced partial responses, representing the first evidence of successful NY-ESO-1 adoptive $\mathrm{T}$ cell therapy in non-melanoma patients. In a follow-up study, the authors expanded their cohort with 9 melanoma and 12 synovial cell sarcoma patients and provided an update on the clinical responses of the first cohort (107). Combining both cohorts, objective responses were obtained in $61 \%$ of patients with synovial cell sarcoma with 5-year overall survival rates of $14 \%$, and in $55 \%$ of melanoma patients with overall 5 -year survival rates of $33 \%$. Furthermore, the same adoptive T cell treatment resulted in near complete or complete response in $80 \%$ of multiple myeloma patients with a median progression-free survival of 19.1 months (108). Numerous clinical trials are currently investigating the safety and efficacy of NY-ESO-1 transduced CD8+ T cells, using NY-ESO-1 either as a single target or as part of a multi-TAA target. While some current trials, summarized in Table 2, study NY-ESO-1 specific or multi-TAA TCR-transduced T cells in a range of advanced solid tumors (NCT03047811, NCT02457650, NCT02869217, NCT02366546), others focus on subgroups of patients with esophageal cancer (NCT01795976), breast cancer (NCT03093350), pancreatic cancer (NCT03192462), rhabdomyosarcoma (NCT02239861), hepatocellular carcinoma (NCT03175705), synovial sarcoma (NCT03250325), or hematological cancers (NCT02494167, NCT02291848). NY-ESO1-specific murine TCR-transduced $\mathrm{T}$ cells in combination with high-dose IL-2 and chemotherapy are currently under evaluation in metastatic cancer patients (NCT02774291, NCT01967823, Table 2). In addition, there are two phase I/II clinical trials investigating the safety and activity of T cell transduction with an affinity-enhanced T cell receptor (TCR) for NY-ESO-1 and LAGE-1 (NY-ESO- $1^{\text {c259 }} \mathrm{T}$ cells) in patients with relapsed or advanced multiple myeloma (NCT01892293, NCT01352286, Table 2). Similarly, adoptive transfer of affinity-enhanced NY-ESO-1 transduced $\mathrm{T}$ cells is under evaluation (Table 2) in metastatic melanoma (NCT01350401), ovarian cancer (NCT01567891), synovial sarcoma (NCT01343043), myxoid/round cell liposarcoma (NCT02992743) and non-small cell lung cancer (NCT03029273, NCT02588612), and in a patient cohort with a variety of advanced solid cancers (NCT03159585). Furthermore, the safety, feasibility, and efficacy of NY-ESO-1 or multi TAA transduced T cell therapy in combination with other modalities is currently under review, including combination with treatment with the demethylating agent Decitabine (NCT03017131, NCT01333046, Table 3), NY-ESO- $1_{157-165}$-pulsed DCs (NCT01697527, Table 3), transduced peripheral blood stem cells (NCT03240861, Table 3), or dominant-negative transforming growth factor-beta receptor II transduced TILs (NCT02650986, Table 3).

Although the majority of adoptive $\mathrm{T}$ cell therapy studies focus on cytotoxic CD8+ T lymphocytes, re-educated CD4+ T cells 
also show potential to eradicate cancer cells. For example, a case study demonstrated that treatment with HLA-DP4-restricted NY-ESO-1 transduced CD4+ T cells can induce complete regression of a refractory metastatic melanoma, with a durable response ongoing at 22 months (109). However, since most cancer cells do not express MHC class II molecules the efficacy of CD4+ based immunotherapy in se is rather limited. Presentation of the HLA-DP restricted NY-ESO- $1_{157-170}$ epitope was enhanced in vitro by directing the antigen to the macro-autophagy pathway using a fusion protein of NY-ESO-1 and the autophagy molecule Atg8/ LC3 (110). The authors also reported that intercellular transfer of NY-ESO-1 by endocytosis increased antigen presentation. Therefore, agents targeting NY-ESO-1 cellular release and/or macro-autophagy could provide a new avenue to improve CD4+ immunotherapy. The lack of MHC class II tumor expression can also be addressed by engineering CD4+ T cells that can recognize HLA-class I-restricted peptides. Using in vitro and in vivo mouse models, this approach was found to induce cancer cell cytotoxicity and cytokine production (111-117). A recent study by Tan et al. demonstrated that HLA-A2-restricted NY-ESO-1 157-165 transduced $\mathrm{CD} 4+\mathrm{T}$ cells displayed higher binding affinity for the peptide than CD8+ T cells and were able to induce cancer cell cytotoxicity (118). These preclinical findings suggest that HLAclass I-redirected CD4+ T cells could improve the antitumor response of current adoptive $\mathrm{T}$ cell therapies.

\section{Combination Treatment With Checkpoint Inhibitors}

The immune response is naturally kept in check by immune checkpoint molecules [cytotoxic T-lymphocyte-associated protein 4 (CTLA-4), programmed cell death protein 1 (PD-1) and programmed death ligand 1 (PD-L1)] in order to prevent over-activation of the immune response resulting in autoimmune disease. While the PD-1 pathway inhibits T cell activation during the effector phase, the CTLA-4 pathway plays an important role in naïve $\mathrm{T}$ cell activation during the priming phase (119). Binding of PD-1 on T cells to its ligands, PD-L1 and programmed death ligand 2, inhibits T-cell proliferation and activation and reduces T cell survival (120). CTLA-4 is a CD28 homolog on the T-cell cell membrane that through competitive binding will inhibit the costimulatory signal of CD28:B7 binding, similarly resulting in reduced $\mathrm{T}$ cell proliferation, differentiation, and survival (121). CTLA-4 expression can also increase T-cell mobility, thereby reducing the contact time between antigen-presenting cells and T-cells and indirectly inhibiting $\mathrm{T}$ cell activation (122). In addition, CTLA-4 is constitutively expressed on regulatory $\mathrm{T}$ cells, which through competitive binding with B7 and/or induction of B7 internalization reduces the availability of B7 on antigenpresenting cells to form the CD28:B7 costimulatory signal for $\mathrm{T}$ cell activation and survival $(123,124)$. Cancer cells can hijack these T-cell regulatory pathways to dampen the antitumor response. One approach in cancer immunotherapy is to unleash the natural immune response by inhibiting these checkpoint molecules using specific inhibitors. Patients who do not respond to immune checkpoint blockade may still benefit from combinatorial treatment with cancer antigen-specific therapy. For instance, treatment with the CTLA-4 checkpoint inhibitor ipilimumab has been reported to induce specific NY-ESO-1 humoral and cellular immune responses in patients with ovarian cancer, prostate cancer, and metastatic melanoma (100, 125-135). Ipilimumab-treated melanoma patients with a NY-ESO-1-specific humoral response at baseline more often experienced an antitumor response and improved survival if accompanied by a NY-ESO-1 specific CD8+ cellular immune response (131).

In addition, NY-ESO-1-specific CD4+ T cells isolated from a metastatic melanoma patient after treatment with ipilimumab were able to directly lyse autologous cancer cells, suggesting an added clinical benefit of eliciting a NY-ESO-1 CD4+ cellular response (134). Together, these findings indicate that combination treatment of checkpoint inhibitors with NY-ESO-1 targeted treatment might result in enhanced and more durable clinical responses. However, this might not be true for all tumor types. Although NY-ESO-1 is highly expressed in sarcoma, antibodies against the antigen are not as common thereby questioning the added clinical benefit of NY-ESO-1 targeted treatment in combination with checkpoint blockade (136-138). Therefore, a pilot phase I trial has been designed to determine the safety and efficacy of combining CTLA-4 blockade with NY-ESO-1 adoptive T cell therapy and NY-ESO-1 vaccination in patients with locally advanced or metastatic malignancies (NCT02070406, Table 3).

Similarly to CTLA-4 inhibition, inhibition of the immune checkpoint molecule PD-1 induces a NY-ESO-1 specific CD8+ cytotoxic immune response (139). Further evidence supporting a potential added benefit from PD-1 inhibition to NY-ESO-1 targeted immunotherapy comes from NY-ESO-1 $1_{157-165}$ peptide vaccination of melanoma patients, demonstrating an upregulation of the T cell inhibitory molecules PD-1, Tim-3 and BTLA in NY-ESO-1 CD8+ T cells (140-143). In vitroblockade of both PD-1 and Tim-3 increased cytotoxic cell proliferation and cytokine secretion of NY-ESO- $1_{157-165}$ CD8+ T cells $(140,144)$. Similarly, tumor-derived NY-ESO- $1_{92-100} \mathrm{CD} 8+\mathrm{T}$ cells isolated from ovarian cancer patients showed an upregulation of the inhibitory molecules PD-1 and LAG-3 with dual blockade enhancing the proliferation and cytokine production (145). Treatment of metastatic melanoma patients with the PD-1 inhibitor nivolumab in combination with the NY-ESO-1 $1_{157-165}$ peptide vaccine revealed that the response rate in both ipilimumab-pretreated and -naive patients was 25\% (146). Serological analyses showed a correlation of high pretreatment NY-ESO-1 CD8+ T cells with disease progression, suggesting that these cells might express several inhibitory molecules, such as Tim-3 and LAG-3. In contrast, no difference in NY-ESO-1 cellular immune response has been observed between non-small cell lung cancer patients responding to PD-1 blockade by nivolumab and non-responders (147). The first experimental evidence supporting the use of PD-1 inhibitors together with NY-ESO-1 adoptive T cell therapy came from a preclinical study using a lung cancer xenograft mouse model (148). In this study, NY-ESO-1 transduced T cells could infiltrate tumors and reduce tumor growth by $50 \%$; however, the cells could not reduce tumor burden and showed upregulation of PD-1, Tim-3, and LAG-3. PD-1 blockade in addition to injection of transduced $\mathrm{T}$ cells reduced the tumor burden with an additional 35\%. Ongoing clinical trials are exploring the safety 
of combining NY-ESO-1 peptide vaccination with Nivolumab (NCT01176461, Table 3), or with both Nivolumab and Ipilimumab (NCT01176474, Table 3). Other trials are determining the safety and feasibility of combining NY-ESO-1 transduced T cell therapy with Nivolumab and NY-ESO-1 peptide-pulsed DC vaccine in advanced solid cancer (NCT02775292, Table 3), or with Pembrozilumab in multiple myeloma (NCT03168438, Table 3). Furthermore, targeting the ligand for PD-1, PD-L1, on tumor cells with Atezolizumab is currently under investigation in combination with NY-ESO-1 pulsed DC vaccination in patients with sarcoma (NCT02609984, Table 3), and in combination with the DEC-205/NY-ESO-1 fusion protein (CDX-1401) vaccine and the demethylation agent guadecitabine in patients with recurrent ovarian, fallopian tube, or primary peritoneal cancer (NCT03206047, Table 3).

\section{WHERE TO GO NEXT?}

NY-ESO-1 targeted treatment has come a long way, targeting the antigen using various approaches from peptide and protein vaccination to adoptive $\mathrm{T}$ cell therapy and combinational treatment modalities. Promising results have been obtained, driving new clinical trials in numerous solid cancers.

Nevertheless, a pressing concern for NY-ESO-1 based therapy is the considerable inter- and intra-heterogeneity of NY-ESO-1 tumor expression, which could significantly limit the extent of tumor cell eradication using NY-ESO-1 targeted treatment. Since the expression of many CTA, including NY-ESO-1, is regulated by methylation, one approach that is being pursued is to increase the tumoral re-expression of NY-ESO-1 by demethylating agents prior to NY-ESO-1 targeted treatment. An early study by Weiser et al. demonstrated that NY-ESO-1 expression could be induced in vitro by treatment with the DNA demethylating agent 5-Aza2 -deoxycytidine, an effect which could be enhanced by sequential treatment with a deacetylase inhibitor (149). Since then, several preclinical studies have shown that demethylation not only increases expression of NY-ESO-1 specifically in tumor cells, but also induces specific CD8+ immune responses and tumor cell cytotoxicity; and when used in combination with NY-ESO-1 immunotherapy it reduced the tumor burden and prolonged the survival in several mouse models (150-155). These experimental findings suggest that epigenetic modulation may enhance or even enable NY-ESO-1 adoptive immunotherapy in poorly immunogenic tumor types.

On another note, even though promising results have been obtained with various NY-ESO-1 cancer vaccine approaches, some reservations need to be made. Since cancer vaccines are often based on synthetic peptides, the question arises whether the induced immune response reflects or complements the natural immune response against endogenous antigen expression. Naturally induced CD8+ immune responses against NY-ESO-1 are commonly directed against an HLA-A2-restricted epitope within the amino acid region 157-165 or 157-167 (156). Comparison of naturally and vaccine-induced CD8+ responses revealed that these cells exhibit structurally conserved but distinct TCR features (157). These findings suggest that synthetic peptides used for vaccination may not accurately reflect the naturally processed antigen and antitumor immune response.
Another important factor to take into account is the impact of the microenvironment on the outcome of immune-modulating treatments. The cancer-immunity cycle is a well-known concept and has become the framework for immunotherapy research. The cancer-immunity cycle describes the various steps that have to be completed to obtain successful eradication of tumor cells, including release of cancer cell antigens, cancer antigen presentation, priming and activation of T cells, trafficking of T cells to tumors, infiltration of $\mathrm{T}$ cells into tumors, recognition of cancer cells by T cells, and finally killing of cancer cells (158). Therefore, the make of the inflammatory milieu and the presence of immune suppressive cells can have a profound effect on treatment efficacy. Tumor cells are capable of escaping the antitumor immune response by hindering each of the steps of the cancer-immunity cycle. First, tumors can escape immune surveillance by altering the expression of tumor antigens. This has raised the concern that the presence of spontaneous tumor antigen-immune responses might induce epitope spreading as a result of prolonged immune pressure. For instance, interim analysis of a phase II study (NCT02609984, Table 3) using a combinatorial approach of PD-L1 inhibition and NY-ESO-1 DC-targeting revealed specific humoral and cellular responses in $50 \%$ of patients with synovial sarcoma and myxoid round cell liposarcoma but also antigen epitope spreading in $20 \%$ of patients (159). Second, the presentation of tumor antigens can also be altered as has been demonstrated in inflammatory melanoma (160). The difference in activity between the non-inflammatory proteasome and the immunoproteasome has been shown to result into a dissimilar repertoire of epitopes that impedes the ability of $\mathrm{T}$ cells to recognize and target the tumor cells.

Third, the presence or induction of immunosuppressive cells can have a profound effect on the treatment outcome. In advanced melanoma it was shown that a single NY-ESO-1 epitope could induce CD4+ T cell responses as well as stimulate $\mathrm{T}$ regulatory cells (161). Further investigation revealed that these specific T regulatory cells are derived from CD4+ CD25- T cells. Hence, inhibition of the peripheral conversion of CD4+ CD25- T cells into specific T regulatory cells may improve treatment outcome. Further, treatment with the NY-ESO-1/ISCOMATRIX vaccine induced NY-ESO-1 specific T regulatory responses, most commonly recognizing the HLA-DP4-restricted NY-ESO-1 ${ }_{157-170}$ peptide (162). In tumor tissue, $\mathrm{T}$ regulatory cells with specificity toward the HLA-DR-restricted NY-ESO- $1_{115-132}$ peptide could be observed. Together, these findings suggest that chronic antigen exposure can result in the suppression of both the circulating and local antitumor immune response through the stimulation and induction of antigen-specific T regulatory T cells. Similarly, chronic hepatitis B infection has been shown to increase the numbers of specific $\mathrm{T}$ regulatory cells in the peripheral blood and liver of patients with hepatocellular carcinoma (163). In vitro investigation of co-culture of peripheral blood mononuclear cells with HBV-transfected hepatoma cell lines revealed an increase in $\mathrm{T}$ regulatory cells together with an upregulation of FoxP3 and the immune checkpoint CTLA-4. Interestingly, these $\mathrm{T}$ regulatory cells were capable of suppressing not only HBVinduced but also NY-ESO-1 tumor antigen-induced immune responses. 


\section{CONCLUDING REMARKS}

Since its discovery, NY-ESO-1 has been investigated as an anticancer target for immune-based interventions. Several approaches have been explored in vitro, in vivo, and in clinical trials. The vast majority of clinical trials focus on solid cancers in the advanced stage. Currently, there are 12 clinical trials registered using a NY-ESO- 1 cancer vaccine, 23 using modified T cells, and 13 using combinatorial immunotherapy. As the field of immunotherapy is evolving, limitations to these approaches are becoming apparent which can be tackled by refining the current methods or addressing them from a different angle as discussed in this review. Exploring such new strategies have resulted in several novel treatments that are currently in clinical trial.

\section{REFERENCES}

1. Almeida LG, Sakabe NJ, deOliveira AR, Silva MCC, Mundstein AS, Cohen T, et al. CTdatabase: a knowledge-base of high-throughput and curated data on cancer-testis antigens. Nucleic Acids Res (2009) 37:D816-9. doi:10.1093/ nar/gkn673

2. Fratta E, Coral S, Covre A, Parisi G, Colizzi F, Danielli R, et al. The biology of cancer testis antigens: putative function, regulation and therapeutic potential. Mol Oncol (2011) 5:164-82. doi:10.1016/j.molonc.2011.02.001

3. Simpson AJG, Caballero OL, Jungbluth A, Chen Y-T, Old LJ. Cancer/ testis antigens, gametogenesis and cancer. Nat Rev Cancer (2005) 5:615-25. doi:10.1038/nrc1669

4. Caballero OL, Chen Y-T. Cancer/testis (CT) antigens: potential targets for immunotherapy. Cancer Sci (2009) 100:2014-21. doi:10.1111/j.1349-7006. 2009.01303.x

5. Rooney MS, Shukla SA, Wu CJ, Getz G, Hacohen N. Molecular and genetic properties of tumors associated with local immune cytolytic activity. Cell (2015) 160:48-61. doi:10.1016/j.cell.2014.12.033

6. Chen Y-T, Ross DS, Chiu R, Zhou XK, Chen Y-Y, Lee P, et al. Multiple cancer/ testis antigens are preferentially expressed in hormone-receptor negative and high-grade breast cancers. PLoS One (2011) 6:e17876. doi:10.1371/journal. pone. 0017876

7. Whitehurst AW. Cause and consequence of cancer/testis antigen activation in cancer. Annu Rev Pharmacol Toxicol (2014) 54:251-72. doi:10.1146/ annurev-pharmtox-011112-140326

8. Smith HA, Cronk RJ, Lang JM, McNeel DG. Expression and immunotherapeutic targeting of the SSX family of cancer-testis antigens in prostate cancer. Cancer Res (2011) 71:6785-95. doi:10.1158/0008-5472.CAN-11-2127

9. Woloszynska-Read A, Mhawech-Fauceglia P, Yu J, Odunsi K, Karpf AR. Intertumor and intratumor NY-ESO-1 expression heterogeneity is associated with promoter-specific and global DNA methylation status in ovarian cancer. Clin Cancer Res (2008) 14:3283-90. doi:10.1158/1078-0432.CCR-07-5279

10. Yegnasubramanian S, Haffner MC, Zhang Y, Gurel B, Cornish TC, Wu Z, et al. DNA hypomethylation arises later in prostate cancer progression than CpG island hypermethylation and contributes to metastatic tumor heterogeneity. Cancer Res (2008) 68:8954-67. doi:10.1158/0008-5472.CAN-07-6088

11. Song X, Song W, Wang Y, Wang J, Li Y, Qian X, et al. MicroRNA-874 functions as a tumor suppressor by targeting cancer/testis antigen HCA587/ MAGE-C2. J Cancer (2016) 7:656-63. doi:10.7150/jca.13674

12. Li H, Chiappinelli KB, Guzzetta AA, Easwaran H, Yen R-WC, Vatapalli R, et al. Immune regulation by low doses of the DNA methyltransferase inhibitor 5-azacitidine in common human epithelial cancers. Oncotarget (2014) 5:587-98. doi:10.18632/oncotarget.1782

13. Karpf AR, Lasek AW, Ririe TO, Hanks AN, Grossman D, Jones DA. Limited gene activation in tumor and normal epithelial cells treated with the DNA methyltransferase inhibitor 5-aza-2'-deoxycytidine. Mol Pharmacol (2004) 65:18-27. doi:10.1124/mol.65.1.18

14. Dubovsky JA, McNeel DG. Inducible expression of a prostate cancer-testis antigen, SSX-2, following treatment with a DNA methylation inhibitor. Prostate (2007) 67:1781-90. doi:10.1002/pros.20665

\section{AUTHOR CONTRIBUTIONS}

JD conceived, designed, and drafted the manuscript. RT and GA-K wrote sections of the manuscript. JR designed the figure and critically revised the manuscript. $\mathrm{WH}, \mathrm{DB}$, and SD critically revised the manuscript and contributed to writing the final manuscript. All authors read and approved the manuscript for publication.

\section{FUNDING}

This work was supported by a grant from the Qatar Biomedical Research Institute (VR80), Qatar Foundation and from the Qatar National Research Fund (JSREP07-010-3-005).

15. Toor AA, Payne KK, Chung HM, Sabo RT, Hazlett AF, Kmieciak M, et al. Epigenetic induction of adaptive immune response in multiple myeloma: sequential azacitidine and lenalidomide generate cancer testis antigen-specific cellularimmunity. BrJ Haematol(2012) 158:700-11.doi:10.1111/j.1365-2141. 2012.09225.x

16. Weber J, Salgaller M, Samid D, Johnson B, Herlyn M, Lassam N, et al. Expression of the MAGE-1 tumor antigen is up-regulated by the demethylating agent 5-aza-2'-deoxycytidine. Cancer Res (1994) 54:1766-71.

17. van der Bruggen P, Traversari C, Chomez P, Lurquin C, Plaen ED, van den Eynde BV, et al. A gene encoding an antigen recognized by cytolytic T lymphocytes on a human melanoma. Science (1991) 254:1643-7. doi:10.1126/ science. 1840703

18. Li Y, Li J, Wang Y, Zhang Y, Chu J, Sun C, et al. Roles of cancer/testis antigens (CTAs) in breast cancer. Cancer Lett (2017) 399:64-73. doi:10.1016/j. canlet.2017.09.006

19. Gjerstorff MF, Andersen MH, Ditzel HJ. Oncogenic cancer/testis antigens: prime candidates for immunotherapy. Oncotarget (2015) 6:15772-87. doi:10.18632/oncotarget.4694

20. Satie A-P, Rajpert-De Meyts E, Spagnoli GC, Henno S, Olivo L, Jacobsen GK, et al. The cancer-testis gene, NY-ESO-1, is expressed in normal fetal and adult testes and in spermatocytic seminomas and testicular carcinoma in situ. Lab Invest (2002) 82:775-80. doi:10.1097/01.LAB.0000017169.26718.5F

21. Jungbluth AA, Chen YT, Stockert E, Busam KJ, Kolb D, Iversen K, et al. Immunohistochemical analysis of NY-ESO-1 antigen expression in normal and malignant human tissues. Int J Cancer (2001) 92:856-60. doi:10.1002/ ijc. 1282

22. Esfandiary A, Ghafouri-Fard S. New York esophageal squamous cell carcinoma-1 and cancer immunotherapy. Immunotherapy (2015) 7:411-39. doi:10.2217/imt.15.3

23. Nicholaou T, Ebert L, Davis ID, Robson N, Klein O, Maraskovsky E, et al. Directions in the immune targeting of cancer: lessons learned from the cancertestis Ag NY-ESO-1. Immunol Cell Biol (2006) 84:303-17. doi:10.1111/ j.1440-1711.2006.01446.x

24. Lethé B, Lucas S, Michaux L, De Smet C, Godelaine D, Serrano A, et al. LAGE-1, a new gene with tumor specificity. Int J Cancer (1998) 76:903-8. doi:10.1002/(SICI)1097-0215(19980610)76:6<903::AID-IJC22>3.0.CO;2-1

25. Alpen B, Güre AO, Scanlan MJ, Old LJ, Chen Y-T. A new member of the NY-ESO-1 gene family is ubiquitously expressed in somatic tissues and evolutionarily conserved. Gene (2002) 297:141-9. doi:10.1016/S0378-1119 (02)00879-X

26. Wang R-F, Wang HY. Immune targets and neoantigens for cancer immunotherapy and precision medicine. Cell Res (2017) 27:11-37. doi:10.1038/ cr.2016.155

27. Kisseleva-Romanova E, Lopreiato R, Baudin-Baillieu A, Rousselle J-C, Ilan L, Hofmann K, et al. Yeast homolog of a cancer-testis antigen defines a new transcription complex. EMBO J (2006) 25:3576-85. doi:10.1038/sj. emboj.7601235

28. Cho HJ, Caballero OL, Gnjatic S, Andrade VCC, Colleoni GW, Vettore AL, et al. Physical interaction of two cancer-testis antigens, MAGE-C1 (CT7) and NY-ESO-1 (CT6). Cancer Immun (2006) 6:12. 
29. Barker PA, Salehi A. The MAGE proteins: emerging roles in cell cycle progression, apoptosis, and neurogenetic disease. J Neurosci Res (2002) 67: 705-12. doi:10.1002/jnr.10160

30. Cronwright G, Le Blanc K, Götherström C, Darcy P, Ehnman M, Brodin B. Cancer/testis antigen expression in human mesenchymal stem cells: downregulation of SSX impairs cell migration and matrix metalloproteinase 2 expression. Cancer Res (2005) 65:2207-15. doi:10.1158/0008-5472.CAN04-1882

31. Yawata T, Nakai E, Park KC, Chihara T, Kumazawa A, Toyonaga S, et al. Enhanced expression of cancer testis antigen genes in glioma stem cells. Mol Carcinog (2010) 49:532-44. doi:10.1002/mc.20614

32. Sharma P, Gnjatic S, Jungbluth AA, Williamson B, Herr H, Stockert E, et al. Frequency of NY-ESO-1 and LAGE-1 expression in bladder cancer and evidence of a new NY-ESO-1 T-cell epitope in a patient with bladder cancer. Cancer Immun (2003) 3:19. doi:10.1186/2051-1426-3-S2-O19

33. Kurashige T, Noguchi Y, Saika T, Ono T, Nagata Y, Jungbluth A, et al. $\mathrm{Ny}$-ESO-1 expression and immunogenicity associated with transitional cell carcinoma: correlation with tumor grade. Cancer Res (2001) 61:4671-4.

34. Bolli M, Schultz-Thater E, Zajac P, Guller U, Feder C, Sanguedolce F, et al. NY-ESO-1/LAGE-1 coexpression with MAGE-A cancer/testis antigens: a tissue microarray study. Int J Cancer (2005) 115:960-6. doi:10.1002/ijc.20953

35. Akcakanat A, Kanda T, Koyama Y, Watanabe M, Kimura E, Yoshida Y, et al. NY-ESO-1 expression and its serum immunoreactivity in esophageal cancer. Cancer Chemother Pharmacol (2004) 54:95-100. doi:10.1007/s00280004-0768-3

36. Prasad ML, Jungbluth AA, Patel SG, Iversen K, Hoshaw-Woodard S, Busam KJ. Expression and significance of cancer testis antigens in primary mucosal melanoma of the head and neck. Head Neck (2004) 26:1053-7. doi:10.1002/hed.10384

37. Odunsi K, Jungbluth AA, Stockert E, Qian F, Gnjatic S, Tammela J, et al. NY-ESO-1 and LAGE-1 cancer-testis antigens are potential targets for immunotherapy in epithelial ovarian cancer. Cancer Res (2003) 63: 6076-83.

38. Fosså A, Berner A, Fosså SD, Hernes E, Gaudernack G, Smeland EB. NY-ESO-1 protein expression and humoral immune responses in prostate cancer. Prostate (2004) 59:440-7. doi:10.1002/pros.20025

39. Oba-Shinjo SM, Caballero OL, Jungbluth AA, Rosemberg S, Old LJ, Simpson AJG, et al. Cancer-testis (CT) antigen expression in medulloblastoma. Cancer Immun (2008) 8:7.

40. Kim SH, Lee S, Lee CH, Lee MK, Kim YD, Shin DH, et al. Expression of cancer-testis antigens MAGE-A3/6 and NY-ESO-1 in non-small-cell lung carcinomas and their relationship with immune cell infiltration. Lung (2009) 187:401-11. doi:10.1007/s00408-009-9181-3

41. Wang Y, Wu X-J, Zhao A-L, Yuan Y-H, Chen Y-T, Jungbluth AA, et al. Cancer/testis antigen expression and autologous humoral immunity to NYESO-1 in gastric cancer. Cancer Immun (2004) 4:11.

42. Aung PP, Liu Y-C, Ballester LY, Robbins PF, Rosenberg SA, Lee C-CR. Expression of New York esophageal squamous cell carcinoma-1 in primary and metastatic melanoma. Hum Pathol (2014) 45:259-67. doi:10.1016/j. humpath.2013.05.029

43. Lai J-P, Robbins PF, Raffeld M, Aung PP, Tsokos M, Rosenberg SA, et al. NY-ESO-1 expression in synovial sarcoma and other mesenchymal tumors: significance for NY-ESO-1-based targeted therapy and differential diagnosis. Mod Pathol (2012) 25:854-8. doi:10.1038/modpathol.2012.31

44. Grigoriadis A, Caballero OL, Hoek KS, da Silva L, Chen Y-T, Shin SJ, et al. CT-X antigen expression in human breast cancer. Proc Natl Acad Sci U S A (2009) 106:13493-8. doi:10.1073/pnas.0906840106

45. Ademuyiwa FO, Bshara W, Attwood K, Morrison C, Edge SB, Ambrosone CB, et al. NY-ESO-1 cancer testis antigen demonstrates high immunogenicity in triple negative breast cancer. PLoS One (2012) 7:e38783. doi:10.1371/journal. pone. 0038783

46. Theurillat J-P, Ingold F, Frei C, Zippelius A, Varga Z, Seifert B, et al. NY-ESO-1 protein expression in primary breast carcinoma and metastases: correlation with CD8+ T-cell and CD79a+ plasmacytic/B-cell infiltration. Int J Cancer (2007) 120:2411-7. doi:10.1002/ijc.22376

47. Hemminger JA, Ewart Toland A, Scharschmidt TJ, Mayerson JL, Kraybill WG, Guttridge DC, et al. The cancer-testis antigen NY-ESO-1 is highly expressed in myxoid and round cell subset of liposarcomas. Mod Pathol (2013) 26:282-8. doi:10.1038/modpathol.2012.133
48. Pollack SM, Jungbluth AA, Hoch BL, Farrar EA, Bleakley M, Schneider DJ, et al. NY-ESO-1 is a ubiquitous immunotherapeutic target antigen for patients with myxoid/round cell liposarcoma. Cancer (2012) 118:4564-70. doi:10.1002/cncr.27446

49. Jungbluth AA, Antonescu CR, Busam KJ, Iversen K, Kolb D, Coplan K, et al. Monophasic and biphasic synovial sarcomas abundantly express cancer/ testis antigen NY-ESO-1 but not MAGE-A1 or CT7. Int J Cancer (2001) 94: 252-6. doi:10.1002/ijc. 1451

50. Rodolfo M, Luksch R, Stockert E, Chen Y-T, Collini P, Ranzani T, et al. Antigen-specific immunity in neuroblastoma patients: antibody and T-cell recognition of NY-ESO-1 tumor antigen. Cancer Res (2003) 63:6948-55.

51. Barrow C, Browning J, MacGregor D, Davis ID, Sturrock S, Jungbluth AA, et al. Tumor antigen expression in melanoma varies according to antigen and stage. Clin Cancer Res (2006) 12:764-71. doi:10.1158/1078-0432.CCR-05-1544

52. Chen YT, Scanlan MJ, Sahin U, Türeci O, Gure AO, Tsang S, et al. A testicular antigen aberrantly expressed in human cancers detected by autologous antibody screening. Proc Natl Acad Sci U S A (1997) 94:1914-8. doi:10.1073/ pnas.94.5.1914

53. Xu Y-W, Peng Y-H, Chen B, Wu Z-Y, Wu J-Y, Shen J-H, et al. Autoantibodies as potential biomarkers for the early detection of esophageal squamous cell carcinoma. Am J Gastroenterol (2014) 109:36-45. doi:10.1038/ajg.2013.384

54. Shan Q, Lou X, Xiao T, Zhang J, Sun H, Gao Y, et al. A cancer/testis antigen microarray to screen autoantibody biomarkers of non-small cell lung cancer. Cancer Lett (2013) 328:160-7. doi:10.1016/j.canlet.2012.08.019

55. Healey GF, Lam S, Boyle P, Hamilton-Fairley G, Peek LJ, Robertson JFR. Signal stratification of autoantibody levels in serum samples and its application to the early detection of lung cancer. J Thorac Dis (2013) 5:618-25. doi:10.3978/j.issn.2072-1439.2013.08.65

56. Yang Z, Chevolot Y, Géhin T, Solassol J, Mange A, Souteyrand E, et al. Improvement of protein immobilization for the elaboration of tumorassociated antigen microarrays: application to the sensitive and specific detection of tumor markers from breast cancer sera. Biosens Bioelectron (2013) 40:385-92. doi:10.1016/j.bios.2012.08.019

57. Fujiwara S, Wada H, Kawada J, Kawabata R, Takahashi T, Fujita J, et al. NY-ESO-1 antibody as a novel tumour marker of gastric cancer. Br J Cancer (2013) 108:1119-25. doi:10.1038/bjc.2013.51

58. Middleton CH, Irving W, Robertson JFR, Murray A, Parsy-Kowalska CB, Macdonald IK, et al. Serum autoantibody measurement for the detection of hepatocellular carcinoma. PLoS One (2014) 9:e103867. doi:10.1371/journal. pone. 0103867

59. Long Y-Y, Wang Y, Huang Q-R, Zheng G-S, Jiao S-C. Measurement of serum antibodies against NY-ESO-1 by ELISA: a guide for the treatment of specific immunotherapy for patients with advanced colorectal cancer. Exp Ther Med (2014) 8:1279-84. doi:10.3892/etm.2014.1913

60. Nakamura S, Nouso K, Noguchi Y, Higashi T, Ono T, Jungbluth A, et al. Expression and immunogenicity of NY-ESO-1 in hepatocellular carcinoma. J Gastroenterol Hepatol (2006) 21:1281-5. doi:10.1111/j.1440-1746. 2006.04271.x

61. Gati A, Lajmi N, Derouiche A, Marrakchi R, Chebil M, BenammarElgaaied A. NY-ESO-1 expression and immunogenicity in prostate cancer patients. Tunis Med (2011) 89:779-83.

62. Oshima Y, Shimada H, Yajima S, Nanami T, Matsushita K, Nomura F, et al. NY-ESO-1 autoantibody as a tumor-specific biomarker for esophageal cancer: screening in 1969 patients with various cancers. J Gastroenterol (2016) 51:30-4. doi:10.1007/s00535-015-1078-8

63. Jäger E, Chen YT, Drijfhout JW, Karbach J, Ringhoffer M, Jäger D, et al. Simultaneous humoral and cellular immune response against cancer-testis antigen NY-ESO-1: definition of human histocompatibility leukocyte antigen (HLA)-A2-binding peptide epitopes. JExp Med (1998) 187:265-70. doi:10.1084/jem.187.2.265

64. Jäger E, Nagata Y, Gnjatic S, Wada H, Stockert E, Karbach J, et al. Monitoring CD8 T cell responses to NY-ESO-1: correlation of humoral and cellular immune responses. Proc Natl Acad Sci U S A (2000) 97:4760-5. doi:10.1073/ pnas.97.9.4760

65. Jäger E, Jäger D, Karbach J, Chen Y-T, Ritter G, Nagata Y, et al. Identification of Ny-Eso-1 epitopes presented by human histocompatibility antigen (Hla)Drb4 ${ }^{*} 0101-0103$ and recognized by Cd4+T lymphocytes of patients with Ny-Eso-1-expressing melanoma. J Exp Med (2000) 191:625-30. doi:10.1084/ jem.191.4.625 
66. Zeng G, Touloukian CE, Wang X, Restifo NP, Rosenberg SA, Wang R-F. Identification of CD4+ T cell epitopes from NY-ESO-1 presented by HLA-DR molecules. J Immunol (2000) 165:1153-9. doi:10.4049/jimmunol.165.2.1153

67. Zarour HM, Storkus WJ, Brusic V, Williams E, Kirkwood JM. NY-ESO-1 encodes DRB1 ${ }^{*} 0401$-restricted epitopes recognized by melanoma-reactive CD4+ T cells. Cancer Res (2000) 60:4946-52.

68. Zarour HM, Maillere B, Brusic V, Coval K, Williams E, Pouvelle-Moratille S, et al. NY-ESO-1 119-143 is a promiscuous major histocompatibility complex class II T-helper epitope recognized by Th1- and Th2-type tumor-reactive CD4+ T cells. Cancer Res (2002) 62:213-8.

69. Gnjatic S, Atanackovic D, Jäger E, Matsuo M, Selvakumar A, Altorki NK, et al. Survey of naturally occurring CD4+ T cell responses against NY-ESO-1 in cancer patients: correlation with antibody responses. Proc Natl Acad Sci U S A (2003) 100:8862-7. doi:10.1073/pnas.1133324100

70. Zeng G, Wang X, Robbins PF, Rosenberg SA, Wang R-F. CD4+ T cell recognition of MHC class II-restricted epitopes from NY-ESO-1 presented by a prevalent HLA DP4 allele: association with NY-ESO-1 antibody production. Proc Natl Acad Sci U S A (2001) 98:3964-9. doi:10.1073/pnas.061507398

71. Danke NA, Koelle DM, Yee C, Beheray S, Kwok WW. Autoreactive T cells in healthy individuals. J Immunol (2004) 172:5967-72. doi:10.4049/ jimmunol.172.10.5967

72. Nishikawa H, Jäger E, Ritter G, Old LJ, Gnjatic S. CD4+ CD25+ regulatory $\mathrm{T}$ cells control the induction of antigen-specific $\mathrm{CD} 4+$ helper $\mathrm{T}$ cell responses in cancer patients. Blood (2005) 106:1008-11. doi:10.1182/blood-200502-0607

73. Stockert E, Jäger E, Chen YT, Scanlan MJ, Gout I, Karbach J, et al. A survey of the humoral immune response of cancer patients to a panel of human tumor antigens. J Exp Med (1998) 187:1349-54. doi:10.1084/jem.187.8.1349

74. Nakada T, Noguchi Y, Satoh S, Ono T, Saika T, Kurashige T, et al. NY-ESO-1 mRNA expression and immunogenicity in advanced prostate cancer. Cancer Immun (2003) 3:10.

75. Goydos JS, Patel M, Shih W. NY-ESO-1 and CTp11 expression may correlate with stage of progression in melanoma. J Surg Res (2001) 98:76-80. doi:10.1006/jsre.2001.6148

76. Konishi J, Toyooka S, Aoe M, Omura Y, Washio K, Tsukuda K, et al. The relationship between NY-ESO-1 mRNA expression and clinicopathological features in non-small cell lung cancer. Oncol Rep (2004) 11:1063-7. doi:10.3892/or.11.5.1063

77. Svobodová S, Browning J, MacGregor D, Pollara G, Scolyer RA, Murali R, et al. Cancer-testis antigen expression in primary cutaneous melanoma has independent prognostic value comparable to that of Breslow thickness, ulceration and mitotic rate. Eur J Cancer (2011) 47:460-9. doi:10.1016/j. ejca.2010.09.042

78. Gure AO, Chua R, Williamson B, Gonen M, Ferrera CA, Gnjatic S, et al. Cancer-testis genes are coordinately expressed and are markers of poor outcome in non-small cell lung cancer. Clin Cancer Res (2005) 11:8055-62. doi:10.1158/1078-0432.CCR-05-1203

79. Laban S, Atanackovic D, Luetkens T, Knecht R, Busch C-J, Freytag M, et al. Simultaneous cytoplasmic and nuclear protein expression of melanoma antigenA family and NY-ESO-1 cancer-testis antigens represents an independent marker for poor survival in head and neck cancer. Int J Cancer (2014) 135: 1142-52. doi:10.1002/ijc.28752

80. van Rhee F, Szmania SM, Zhan F, Gupta SK, Pomtree M, Lin P, et al. NY-ESO-1 is highly expressed in poor-prognosis multiple myeloma and induces spontaneous humoral and cellular immune responses. Blood (2005) 105:3939-44. doi:10.1182/blood-2004-09-3707

81. Peng J, Chen H, Mou D, Cao J, Cong X, Qin L, et al. Expression of cancer/ testis (CT) antigens in Chinese hepatocellular carcinoma and its correlation with clinical parameters. Cancer Lett (2005) 219:223-32. doi:10.1016/j. canlet.2004.07.028

82. Xu H, Gu N, Liu Z-B, Zheng M, Xiong F, Wang S-Y, et al. NY-ESO-1 expression in hepatocellular carcinoma: a potential new marker for early recurrence after surgery. Oncol Lett (2012) 3:39-44. doi:10.3892/ol.2011.441

83. Perez D, Hauswirth F, Jäger D, Metzger U, Samartzis EP, Went P, et al. Protein expression of cancer testis antigens predicts tumor recurrence and treatment response to imatinib in gastrointestinal stromal tumors. Int J Cancer (2011) 128:2947-52. doi:10.1002/ijc. 25836

84. Inaoka RJ, Jungbluth AA, Gnjatic S, Ritter E, Hanson NC, Frosina D, et al. Cancer/testis antigens expression and autologous serological response in a set of Brazilian non-Hodgkin's lymphoma patients. Cancer Immunol Immunother (2012) 61:2207-14. doi:10.1007/s00262-012-1285-6

85. Mischo A, Kubuschok B, Ertan K, Preuss K-D, Romeike B, Regitz E, et al. Prospective study on the expression of cancer testis genes and antibody responses in 100 consecutive patients with primary breast cancer. Int J Cancer (2006) 118:696-703. doi:10.1002/ijc.21352

86. Badovinac Črnjević T, Spagnoli G, Juretić A, Jakić-Razumović J, Podolski P, Šarić N. High expression of MAGE-A10 cancer-testis antigen in triplenegative breast cancer. Med Oncol (2012) 29:1586-91. doi:10.1007/s12032011-0120-9

87. Luetkens T, Kobold S, Cao Y, Ristic M, Schilling G, Tams S, et al. Functional autoantibodies against SSX-2 and NY-ESO-1 in multiple myeloma patients after allogeneic stem cell transplantation. Cancer Immunol Immunother (2014) 63:1151-62. doi:10.1007/s00262-014-1588-x

88. Jäger E, Stockert E, Zidianakis Z, Chen YT, Karbach J, Jäger D, et al. Humoral immune responses of cancer patients against "cancer-testis" antigen NY-ESO-1: correlation with clinical events. Int J Cancer (1999) 84:506-10. doi:10.1002/(SICI)1097-0215(19991022)84:5<506::AID-IJC10>3.0.CO;2-6

89. Li Y, Song R, Li X, Xu F. Expression and immunogenicity of NY-ESO-1 in colorectal cancer. Exp Ther Med (2017) 13:3581-5. doi:10.3892/etm.2017. 4405

90. Weide B, Zelba H, Derhovanessian E, Pflugfelder A, Eigentler TK, Di Giacomo AM, et al. Functional T cells targeting NY-ESO-1 or Melan-A are predictive for survival of patients with distant melanoma metastasis. J Clin Oncol (2012) 30:1835-41. doi:10.1200/JCO.2011.40.2271

91. Kageyama S, Wada H, Muro K, Niwa Y, Ueda S, Miyata H, et al. Dosedependent effects of NY-ESO-1 protein vaccine complexed with cholesteryl pullulan (CHP-NY-ESO-1) on immune responses and survival benefits of esophagealcancerpatients.J TranslMed(2013) 11:246. doi:10.1186/1479-587611-246

92. Tsuji T, Sabbatini P, Jungbluth AA, Ritter E, Pan L, Ritter G, et al. Effect of Montanide and poly-ICLC adjuvant on human self/tumor antigen-specific $\mathrm{CD} 4+\mathrm{T}$ cells in phase I overlapping long peptide vaccine trial. Cancer Immunol Res (2013) 1:340-50. doi:10.1158/2326-6066.CIR-13-0089

93. Li M, Shi H, Mu Y, Luo Z, Zhang H, Wan Y, et al. Effective inhibition of melanoma tumorigenesis and growth via a new complex vaccine based on NYESO-1-alum-polysaccharide-HH2. Mol Cancer (2014) 13:179. doi:10.1186/ 1476-4598-13-179

94. Davis ID, Chen W, Jackson H, Parente P, Shackleton M, Hopkins W, et al. Recombinant NY-ESO-1 protein with ISCOMATRIX adjuvant induces broad integrated antibody and CD4(+) and CD8(+) T cell responses in humans. Proc Natl Acad Sci U S A (2004) 101:10697-702. doi:10.1073/pnas. 0403572101

95. Kakimi K, Isobe M, Uenaka A, Wada H, Sato E, Doki Y, et al. A phase I study of vaccination with NY-ESO-1f peptide mixed with Picibanil OK-432 and Montanide ISA-51 in patients with cancers expressing the NY-ESO-1 antigen. Int J Cancer (2011) 129:2836-46. doi:10.1002/ijc.25955

96. Odunsi K, Matsuzaki J, Karbach J, Neumann A, Mhawech-Fauceglia P, Miller A, et al. Efficacy of vaccination with recombinant vaccinia and fowlpox vectors expressing NY-ESO-1 antigen in ovarian cancer and melanoma patients. Proc Natl Acad Sci U S A (2012) 109:5797-802. doi:10.1073/pnas. 1117208109

97. Jäger E, Karbach J, Gnjatic S, Neumann A, Bender A, Valmori D, et al. Recombinant vaccinia/fowlpox NY-ESO-1 vaccines induce both humoral and cellular NY-ESO-1-specific immune responses in cancer patients. Proc Natl Acad Sci U S A (2006) 103:14453-8. doi:10.1073/pnas.0606512103

98. Engell-Noerregaard L, Hansen TH, Andersen MH, Thor Straten P, Svane IM. Review of clinical studies on dendritic cell-based vaccination of patients with malignant melanoma: assessment of correlation between clinical response and vaccine parameters. Cancer Immunol Immunother (2009) 58:1-14. doi:10.1007/s00262-008-0568-4

99. van Duin D, Medzhitov R, Shaw AC. Triggering TLR signaling in vaccination. Trends Immunol (2006) 27:49-55. doi:10.1016/j.it.2005.11.005

100. Adams S, O’Neill DW, Nonaka D, Hardin E, Chiriboga L, Siu K, et al. Immunization of malignant melanoma patients with full-length NY-ESO-1 protein using TLR7 agonist imiquimod as vaccine adjuvant. J Immunol (2008) 181:776-84. doi:10.4049/jimmunol.181.1.776

101. Dhodapkar MV, Sznol M, Zhao B, Wang D, Carvajal RD, Keohan ML, et al. Induction of antigen-specific immunity with a vaccine targeting NY-ESO-1 
to the dendritic cell receptor DEC-205. Sci Transl Med (2014) 6:232ra51. doi:10.1126/scitranslmed.3008068

102. Valmori D, Souleimanian NE, Tosello V, Bhardwaj N, Adams S, O’Neill D, et al. Vaccination with NY-ESO-1 protein and CpG in Montanide induces integrated antibody/Th1 responses and CD8 T cells through cross-priming. Proc Natl Acad Sci U S A (2007) 104:8947-52. doi:10.1073/pnas.0703395104

103. Pollack SM, Lu H, Gnjatic S, Somaiah N, O’Malley RB, Jones RL, et al. Firstin-human treatment with a dendritic cell-targeting lentiviral vectorexpressing NY-ESO-1, LV305, induces deep, durable response in refractory metastatic synovial sarcoma patient. J Immunother (2017) 40:302-6. doi:10.1097/ CJI.0000000000000183

104. Cruz LJ, Rueda F, Simón L, Cordobilla B, Albericio F, Domingo JC. Liposomes containing NY-ESO-1/tetanus toxoid and adjuvant peptides targeted to human dendritic cells via the Fc receptor for cancer vaccines. Nanomedicine (2014) 9:435-49. doi:10.2217/NNM.13.66

105. Odunsi K, Matsuzaki J, James SR, Mhawech-Fauceglia P, Tsuji T, Miller A, et al. Epigenetic potentiation of NY-ESO-1 vaccine therapy in human ovarian cancer. Cancer Immunol Res (2014) 2:37-49. doi:10.1158/2326-6066. CIR-13-0126

106. Robbins PF, Morgan RA, Feldman SA, Yang JC, Sherry RM, Dudley ME, et al. Tumor regression in patients with metastatic synovial cell sarcoma and melanoma using genetically engineered lymphocytes reactive with NY-ESO-1. J Clin Oncol (2011) 29:917-24. doi:10.1200/JCO.2010.32.2537

107. Robbins PF, Kassim SH, Tran TLN, Crystal JS, Morgan RA, Feldman SA, et al. A pilot trial using lymphocytes genetically engineered with an NY-ESO-1reactive T-cell receptor: long-term follow-up and correlates with response. Clin Cancer Res (2015) 21:1019-27. doi:10.1158/1078-0432.CCR-14-2708

108. Rapoport AP, Stadtmauer EA, Binder-Scholl GK, Goloubeva O, Vogl DT, Lacey SF, et al. NY-ESO-1-specific TCR-engineered T cells mediate sustained antigen-specific antitumor effects in myeloma. Nat Med (2015) 21:914-21. doi:10.1038/nm.3910

109. Hunder NN, Wallen H, Cao J, Hendricks DW, Reilly JZ, Rodmyre R, et al. Treatment of metastatic melanoma with autologous CD4+ T cells against NY-ESO-1. NEngl J Med (2008) 358:2698-703. doi:10.1056/NEJMoa0800251

110. Fonteneau JF, Brilot F, Münz C, Gannagé M. The tumor antigen NY-ESO-1 mediates direct recognition of melanoma cells by $\mathrm{CD} 4+\mathrm{T}$ cells after intercellular antigen transfer. J Immunol (2016) 196:64-71. doi:10.4049/jimmunol. 1402664

111. Ray S, Chhabra A, Chakraborty NG, Hegde U, Dorsky DI, Chodon T, et al. MHC-I-restricted melanoma antigen specific TCR-engineered human $\mathrm{CD} 4+\mathrm{T}$ cells exhibit multifunctional effector and helper responses, in vitro. Clin Immunol (2010) 136:338-47. doi:10.1016/j.clim.2010.04.013

112. Willemsen R, Ronteltap C, Heuveling M, Debets R, Bolhuis R. Redirecting human CD4+ T lymphocytes to the MHC class I-restricted melanoma antigen MAGE-A1 by TCR alphabeta gene transfer requires CD8alpha. Gene Ther (2005) 12:140-6. doi:10.1038/sj.gt.3302388

113. Tsuji T, Yasukawa M, Matsuzaki J, Ohkuri T, Chamoto K, Wakita D, et al. Generation of tumor-specific, HLA class I-restricted human Th1 and Tc1 cells by cell engineering with tumor peptide-specific T-cell receptor genes. Blood (2005) 106:470-6. doi:10.1182/blood-2004-09-3663

114. Xue S-A, Gao L, Ahmadi M, Ghorashian S, Barros RD, Pospori C, et al. Human MHC Class I-restricted high avidity CD4(+) T cells generated by co-transfer of TCR and CD8 mediate efficient tumor rejection in vivo. Oncoimmunology (2013) 2:e22590. doi:10.4161/onci.22590

115. Morris EC, Tsallios A, Bendle GM, Xue S-A, Stauss HJ. A critical role of $\mathrm{T}$ cell antigen receptor-transduced MHC class I-restricted helper T cells in tumor protection. Proc Natl Acad Sci U S A (2005) 102:7934-9. doi:10.1073/ pnas. 0500357102

116. Chhabra A, Yang L, Wang P, Comin-Anduix B, Das R, Chakraborty NG, et al. CD4+CD25- $\mathrm{T}$ cells transduced to express MHC class I-restricted epitope-specific TCR synthesize Thl cytokines and exhibit MHC class Irestricted cytolytic effector function in a human melanoma model. J Immunol (2008) 181:1063-70. doi:10.4049/jimmunol.181.2.1063

117. Roszkowski JJ, Lyons GE, Kast WM, Yee C, Van Besien K, Nishimura MI. Simultaneous generation of CD8+ and CD4+ melanoma-reactive $\mathrm{T}$ cells by retroviral-mediated transfer of a single T-cell receptor. Cancer Res (2005) 65:1570-6. doi:10.1158/0008-5472.CAN-04-2076

118. Tan MP, Dolton GM, Gerry AB, Brewer JE, Bennett AD, Pumphrey NJ, et al. Human leucocyte antigen class I-redirected anti-tumour CD4(+) T cells require a higher $\mathrm{T}$ cell receptor binding affinity for optimal activity than CD8(+) T cells. Clin Exp Immunol (2017) 187:124-37. doi:10.1111/cei.12828

119. Buchbinder EI, Desai A. CTLA-4 and PD-1 pathways: similarities, differences, and implications of their inhibition. Am J Clin Oncol (2016) 39:98-106. doi:10.1097/COC.0000000000000239

120. Keir ME, Butte MJ, Freeman GJ, Sharpe AH. PD-1 and its ligands in tolerance and immunity. Annu Rev Immunol (2008) 26:677-704. doi:10.1146/annurev. immunol.26.021607.090331

121. Egen JG, Kuhns MS, Allison JP. CTLA-4: new insights into its biological function and use in tumor immunotherapy. Nat Immunol (2002) 3:611-8. doi:10.1038/ni0702-611

122. Schneider H, Downey J, Smith A, Zinselmeyer BH, Rush C, Brewer JM, et al. Reversal of the TCR stop signal by CTLA-4. Science (2006) 313:1972-5. doi:10.1126/science.1131078

123. Wing K, Onishi Y, Prieto-Martin P, Yamaguchi T, Miyara M, Fehervari Z, et al. CTLA-4 control over Foxp3+ regulatory T cell function. Science (2008) 322:271-5. doi:10.1126/science.1160062

124. Qureshi OS, Zheng Y, Nakamura K, Attridge K, Manzotti C, Schmidt EM, et al. Trans-endocytosis of CD80 and CD86: a molecular basis for the cell-extrinsic function of CTLA-4. Science (2011) 332:600-3. doi:10.1126/science.1202947

125. Hodi FS, Butler M, Oble DA, Seiden MV, Haluska FG, Kruse A, et al. Immunologic and clinical effects of antibody blockade of cytotoxic T lymphocyte-associated antigen 4 in previously vaccinated cancer patients. Proc Natl Acad Sci U S A (2008) 105:3005-10. doi:10.1073/pnas.0712237105

126. Yuan J, Gnjatic S, Li H, Powel S, Gallardo HF, Ritter E, et al. CTLA-4 blockade enhances polyfunctional NY-ESO-1 specific $\mathrm{T}$ cell responses in metastatic melanoma patients with clinical benefit. Proc Natl Acad Sci U S A (2008) 105:20410-5. doi:10.1073/pnas.0810114105

127. Goff SL, Robbins PF, El-Gamil M, Rosenberg SA. No correlation between clinical response to CTLA-4 blockade and presence of NY-ESO-1 antibody in patients with metastatic melanoma. JImmunother (2009) 32:884-5. doi:10.1097/CJI.0b013e3181affbf0

128. Yuan J, Ginsberg B, Page D, Li Y, Rasalan T, Gallardo HF, et al. CTLA-4 blockade increases antigen-specific CD8(+) T cells in prevaccinated patients with melanoma: three cases. Cancer Immunol Immunother (2011) 60: 1137-46. doi:10.1007/s00262-011-1011-9

129. Fong L, Kwek SS, O’Brien S, Kavanagh B, McNeel DG, Weinberg V, et al. Potentiating endogenous antitumor immunity to prostate cancer through combination immunotherapy with CTLA4 blockade and GM-CSF. Cancer Res (2009) 69:609-15. doi:10.1158/0008-5472.CAN-08-3529

130. Liakou CI, Kamat A, Tang DN, Chen H, Sun J, Troncoso P, et al. CTLA-4 blockade increases IFNgamma-producing CD4+ICOShi cells to shift the ratio of effector to regulatory $\mathrm{T}$ cells in cancer patients. Proc Natl Acad Sci U S A (2008) 105:14987-92. doi:10.1073/pnas.0806075105

131. Yuan J, Adamow M, Ginsberg BA, Rasalan TS, Ritter E, Gallardo HF, et al. Integrated NY-ESO-1 antibody and CD8+ T-cell responses correlate with clinical benefit in advanced melanoma patients treated with ipilimumab. Proc Natl Acad Sci U S A (2011) 108:16723-8. doi:10.1073/pnas.1110814108

132. Sioud M, Nyakas M, Saebøe-Larssen S, Mobergslien A, Aamdal S, Kvalheim G. Diversification of antitumour immunity in a patient with metastatic melanoma treated with ipilimumab and an IDO-silenced dendritic cell vaccine. Case Rep Med (2016) 2016:9639585. doi:10.1155/2016/ 9639585

133. Dos Santos LI, Galvão-Filho B, de Faria PC, Junqueira C, Dutra MS, Teixeira SMR, et al. Blockade of CTLA-4 promotes the development of effector CD8+ T lymphocytes and the therapeutic effect of vaccination with an attenuated protozoan expressing NY-ESO-1. Cancer Immunol Immunother (2015) 64:311-23. doi:10.1007/s00262-014-1634-8

134. Kitano S, Tsuji T, Liu C, Hirschhorn-Cymerman D, Kyi C, Mu Z, et al. Enhancement of tumor-reactive cytotoxic CD4+ $\mathrm{T}$ cell responses after ipilimumab treatment in four advanced melanoma patients. Cancer Immunol Res (2013) 1:235-44. doi:10.1158/2326-6066.CIR-13-0068

135. Weber JS, Hamid O, Chasalow SD, Wu DY, Parker SM, Galbraith S, et al. Ipilimumab increases activated $\mathrm{T}$ cells and enhances humoral immunity in patients with advanced melanoma. JImmunother (2012) 35:89-97. doi:10.1097/CJI.0b013e31823aa41c

136. Ayyoub M, Taub RN, Keohan M-L, Hesdorffer M, Metthez G, Memeo L, et al. The frequent expression of cancer/testis antigens provides opportunities for immunotherapeutic targeting of sarcoma. Cancer Immun (2004) 4:7. 
137. Lee S-Y, Obata Y, Yoshida M, Stockert E, Williamson B, Jungbluth AA, et al. Immunomic analysis of human sarcoma. Proc Natl Acad Sci U S A (2003) 100:2651-6. doi:10.1073/pnas.0437972100

138. Maki RG, Jungbluth AA, Gnjatic S, Schwartz GK, D’Adamo DR, Keohan ML, et al. A pilot study of anti-CTLA4 antibody ipilimumab in patients with synovial sarcoma. Sarcoma (2013) 2013:168145. doi:10.1155/2013/168145

139. Gibney GT, Kudchadkar RR, DeConti RC, Thebeau MS, Czupryn MP, Tetteh L, et al. Safety, correlative markers, and clinical results of adjuvant nivolumab in combination with vaccine in resected high-risk metastatic melanoma. Clin Cancer Res (2015) 21:712-20. doi:10.1158/1078-0432.CCR-14-2468

140. Fourcade J, Sun Z, Pagliano O, Chauvin J-M, Sander C, Janjic B, et al. PD-1 and Tim-3 regulate the expansion of tumor antigen-specific CD8 ${ }^{+}$ $\mathrm{T}$ cells induced by melanoma vaccines. Cancer Res (2014) 74:1045-55. doi:10.1158/0008-5472.CAN-13-2908

141. Fourcade J, Sun Z, Pagliano O, Guillaume P, Luescher IF, Sander C, et al. CD8(+) T cells specific for tumor antigens can be rendered dysfunctional by the tumor microenvironment through upregulation of the inhibitory receptors BTLA and PD-1. Cancer Res (2012) 72:887-96. doi:10.1158/0008-5472. CAN-11-2637

142. Fourcade J, Sun Z, Benallaoua M, Guillaume P, Luescher IF, Sander C, et al. Upregulation of Tim-3 and PD-1 expression is associated with tumor antigen-specific CD8+ T cell dysfunction in melanoma patients. J Exp Med (2010) 207:2175-86. doi:10.1084/jem.20100637

143. Tarhini AA, Edington H, Butterfield LH, Lin Y, Shuai Y, Tawbi H, et al. Immune monitoring of the circulation and the tumor microenvironment in patients with regionally advanced melanoma receiving neoadjuvant ipilimumab. PLoS One (2014) 9:e87705. doi:10.1371/journal.pone.0087705

144. Fourcade J, Kudela P, Sun Z, Shen H, Land SR, Lenzner D, et al. PD-1 is a regulator of NY-ESO-1-specific CD8+ $\mathrm{T}$ cell expansion in melanoma patients. J Immunol (2009) 182:5240-9. doi:10.4049/jimmunol.0803245

145. Matsuzaki J, Gnjatic S, Mhawech-Fauceglia P, Beck A, Miller A, Tsuji T, et al. Tumor-infiltrating NY-ESO-1-specific CD8+ T cells are negatively regulated by LAG-3 and PD-1 in human ovarian cancer. Proc Natl Acad Sci US A (2010) 107:7875-80. doi:10.1073/pnas.1003345107

146. Weber JS, Kudchadkar RR, Yu B, Gallenstein D, Horak CE, Inzunza HD, et al. Safety, efficacy, and biomarkers of nivolumab with vaccine in ipilimumabrefractory or -naive melanoma. J Clin Oncol (2013) 31:4311-8. doi:10.1200/ JCO.2013.51.4802

147. Dhodapkar KM, Gettinger SN, Das R, Zebroski H, Dhodapkar MV. SOX2-specific adaptive immunity and response to immunotherapy in nonsmall cell lung cancer. Oncoimmunology (2013) 2:e25205. doi:10.4161/onci. 25205

148. Moon EK, Ranganathan R, Eruslanov E, Kim S, Newick K, O’Brien S, et al. Blockade of programmed death 1 augments the ability of human T cells engineered to target NY-ESO-1 to control tumor growth after adoptive transfer. Clin Cancer Res (2016) 22:436-47. doi:10.1158/1078-0432.CCR-15-1070

149. Weiser TS, Guo ZS, Ohnmacht GA, Parkhurst ML, Tong-On P, Marincola FM, et al. Sequential 5-Aza-2 deoxycytidine-depsipeptide FR901228 treatment induces apoptosis preferentially in cancer cells and facilitates their recognition by cytolytic T lymphocytes specific for NY-ESO-1. J Immunother (2001) 24:151-61.

150. Klar AS, Gopinadh J, Kleber S, Wadle A, Renner C. Treatment with 5-Aza2'-deoxycytidine induces expression of NY-ESO-1 and facilitates cytotoxic T lymphocyte-mediated tumor cell killing. PLoS One (2015) 10:e0139221. doi:10.1371/journal.pone.0139221

151. Li B, Zhu X, Sun L, Yuan L, Zhang J, Li H, et al. Induction of a specific CD8+ T-cell response to cancer/testis antigens by demethylating pre-treatment against osteosarcoma. Oncotarget (2014) 5:10791-802. doi:10.18632/oncotarget.2505
152. Gunda V, Frederick DT, Bernasconi MJ, Wargo JA, Parangi S. A potential role for immunotherapy in thyroid cancer by enhancing NY-ESO-1 cancer antigen expression. Thyroid (2014) 24:1241-50. doi:10.1089/thy.2013. 0680

153. Chou J, Voong LN, Mortales CL, Towlerton AMH, Pollack SM, Chen X, et al. Epigenetic modulation to enable antigen-specific T-cell therapy of colorectal cancer. J Immunother (2012) 35:131-41. doi:10.1097/CJI.0b013e31824300c7

154. Pollack SM, Li Y, Blaisdell MJ, Farrar EA, Chou J, Hoch BL, et al. NYESO-1/ LAGE-1s and PRAME are targets for antigen specific $\mathrm{T}$ cells in chondrosarcoma following treatment with 5-Aza-2-deoxycitabine. PLoS One (2012) 7:e32165. doi:10.1371/journal.pone.0032165

155. Natsume A, Wakabayashi T, Tsujimura K, Shimato S, Ito M, Kuzushima K, et al. The DNA demethylating agent 5-aza-2'-deoxycytidine activates NYESO-1 antigenicity in orthotopic human glioma. Int J Cancer (2008) 122: 2542-53. doi:10.1002/ijc.23407

156. Held G, Matsuo M, Epel M, Gnjatic S, Ritter G, Lee SY, et al. Dissecting cytotoxic T cell responses towards the NY-ESO-1 protein by peptide/MHCspecific antibody fragments. Eur J Immunol (2004) 34:2919-29. doi:10.1002/ eji.200425297

157. Le Gal F-A, Ayyoub M, Dutoit V, Widmer V, Jäger E, Cerottini J-C, et al. Distinct structural TCR repertoires in naturally occurring versus vaccineinduced CD8+ T-cell responses to the tumor-specific antigen NY-ESO-1. J Immunother (2005) 28:252-7.

158. Chen DS, Mellman I. Oncology meets immunology: the cancer-immunity cycle. Immunity (2013) 39:1-10. doi:10.1016/j.immuni.2013.07.012

159. Chawla S, Van Tine BA, Pollack S, Ganjoo K, Elias A, Riedel RF, et al. 1480PDA phase 2 study of CMB305 and atezolizumab in NY-ESO-1+ soft tissue sarcoma: interim analysis of immunogenicity, tumor control and survival. Ann Oncol (2017) 28:mdx387.007. doi:10.1093/annonc/ mdx387.007

160. Woods K, Knights AJ, Anaka M, Schittenhelm RB, Purcell AW, Behren A, et al. Mismatch in epitope specificities between IFN $\gamma$ inflamed and uninflamed conditions leads to escape from T lymphocyte killing in melanoma. J Immunother Cancer (2016) 4:10. doi:10.1186/s40425-016-0111-7

161. Fourcade J, Sun Z, Kudela P, Janjic B, Kirkwood JM, El-Hafnawy T, et al. Human tumor antigen-specific helper and regulatory $\mathrm{T}$ cells share common epitope specificity but exhibit distinct T cell repertoire. J Immunol (2010) 184:6709-18. doi:10.4049/jimmunol.0903612

162. Ebert LM, MacRaild SE, Zanker D, Davis ID, Cebon J, Chen W. A cancer vaccine induces expansion of NY-ESO-1-specific regulatory $\mathrm{T}$ cells in patients with advanced melanoma. PLoS One (2012) 7:e48424. doi:10.1371/ journal.pone.0048424

163. Zhang HH, Mei MH, Fei R, Liu F, Wang JH, Liao WJ, et al. Regulatory T cells in chronic hepatitis B patients affect the immunopathogenesis of hepatocellular carcinoma by suppressing the anti-tumour immune responses. J Viral Hepat (2010) 17(Suppl 1):34-43. doi:10.1111/j.1365-2893.2010.01269.x

Conflict of Interest Statement: The authors declare that the research was conducted in the absence of any commercial or financial relationships that could be construed as a potential conflict of interest.

Copyright (C) 2018 Thomas, Al-Khadairi, Roelands, Hendrickx, Dermime, Bedognetti and Decock. This is an open-access article distributed under the terms of the Creative Commons Attribution License (CC BY). The use, distribution or reproduction in other forums is permitted, provided the original author(s) and the copyright owner are credited and that the original publication in this journal is cited, in accordance with accepted academic practice. No use, distribution or reproduction is permitted which does not comply with these terms. 